\title{
Overview of Gulf of Mottama Wetland (GoMW) \& Size Distri- bution and Economic Status of Sea Bass in Myanmar
}

\author{
Phyoe Marnn ${ }^{1}$, Chunguang He ${ }^{1 *}$, Haider Ali', Soe Moe Tun ${ }^{2}$, Khin Swe Wynn ${ }^{3}$, Nyein Nyein Moe ${ }^{3}$, Tao Yang ${ }^{1}$, \\ Nizeyimana Jean Claude ${ }^{4}$, Muhammad Hasnain ${ }^{1}$, Thaw Tar $\mathrm{Oo}^{5}$ and Yousef A. Al-Masnay ${ }^{6}$
}

1 State Environmental Protection Key Laboratory of Wetland Ecology and Vegetation Restoration, School of Environment, Northeast Normal University, Changchun 130117, China; feie337@nenu.edu.cn (P.M); hecg@nenu.edu.cn (C.H); haid555@nenu.edu.cn (H.A); yangt843@nenu.edu.cn (T.Y); hasy663@nenu.edu.cn (M.H)

2 Department of Zoology, Hpa-An University, Hpa-An 13017, Kayin State, Myanmar; soemoetun991@gmail.com (S.M.H)

3 Department of Zoology, Bago University, Bago Division 08018, Myanmar; doristun125@gmail.com (K.S.W); nyeinmoe1970@gmail.com (N.N.M)

4 Key Laboratory of Water Pollution Control Engineering, Northeast Normal University, Changchun 130024 China; yangl176@nenu.edu.cn (N.J.C)

5 Department of Myanmar, University of Distance Education, Bago University, Bago Division, 08018, Myanmar; oot30148@gmail.com (T.T.O)

6 Institute of Natural Disaster Research, Northeast Normal University, Changchun 130024, China; yues271@nenu.edu.cn (Y.A. Al-M)

* Correspondence: he-cg@nenu.edu.cn

\begin{abstract}
The present study was conducted the status of sea bass from Kokko and Kyuntone of The Gulf of Motttama Wetland (GoMW) area in Thanatpin Township in Bago Region Myanmar from September 2019 to August 2020. Fifty specimens were monthly collected, measured and weighed. Invoices of sea bass were collected for the depot and fish sellers by monthly. In Kokko, mean value of standard length and body weight were highest in March (32.70 $\pm 1.58,660.7 \pm 112.23)$. The mean value of standard length was peak in January (31.39 \pm 7.16$)$ but peak of body weight was in March (963.24 \pm 280.86$)$ in Kyuntone villages. The lowest mean value of standard length and body weight were found in June at both study areas. According to the invoice data revealed that monthly catch weight of sea bass is most abundance in October (829.92) kg in Kokko, (339.12) kg in Kyuntone. Based on price of relations to size group, small size C $<300 \mathrm{~g}(41 \%)$ was mostly abundance in Kokko and in Kyuntone small size C $<300 \mathrm{~g}(35 \%)$ was second abundance. Specimens were not landed in April and May. In June, young specimens were very rarely seen in both study sites. The important roles of wetland fishes, the economic valuation of GOMW in Myanmar and samples of fishing gear and value chain of sea bass in Myanmar was expressed in this study.
\end{abstract}

Keywords: The Gulf of Mottama Wetland; Morphometric measurement; catch weight; size group

\section{Introduction}

Sea bass fishes are family Latidae of the order Perciformes. Sea bass are found in coastal waters, estuaries and fresh streams. They are catadromous in that they migrate from freshwater back to estuaries and oceanic water to spawn and then return to fresh water [42-49]. Lates uwisara (Barramudi) are valuable both as recreational and commercial fish with a high fairly stable price. They are stocked in lake and ponds for recreational fishery and are also fished in freshwater creeks and estuaries [41-48, 74, 97, 136, 151]. In Myanmar, sea bass has both domestic and international demand and can be grown in fresh, salt or seawater. Over the past decade, the market for sea bass has markedly in the Myeik archipelago in Tanintharyi Region as well as in Yangon and also Ayeyarwady regions. Myeik which has been commercially breeding sea bass for 10 years [156,158]. The Gulf of Mottama wetland (GoMW) conservation area was declared the sixth Ramsar Site 
in Myanmar on Wednesday, on 10 May 2017 [25,26,99,118-120,139-141]. The Gulf of Mottama Wetland (GoMW) of which situated at the mouth of Sittaung River is considered a unique estuarine mudflat environment that is home to a great variety of flora and fauna $[33,36,130,139]$. This Gulf supports a large number of species such as marine avifauna, invertebrates and up to 150,000 migratory water birds in non- breeding season [1,25,26, 38, 39]. The gulf of Mottama wetland (GoMW) also supports thousands of local and regional people by providing fishes and vegetation [7,24,121-123]. On the world, one billion people rely on fishes as sole source of protein and 35 million people are directly engaged with fisheries and $95 \%$ of them live in developing countries and the majority are smallscale fishers [101, 139, 153, 155]. The new coverage would be broadened to include the areas from Thaton and Paung Townships in Mon state to Kawa and Thanatpin Township in Bago $[103,140,141,143,156]$. In Myanmar, wetland fishes are vital role of wetland economic valuation and ecosystem of wetland $[3,51,60,67]$. The direct value of wetland fishes is local trading and international trading in Myanmar wetland areas. Ecosystem of Wetlands support resident fishes that both play vital roles in the aquatic -terrestrial trophic web $[9,10,20,27]$ and provide recreational and commercial fisheries harvests worth billions of dollars annually $[40,89,124,135]$. The community structure of fishes can predict important informations for climatic signals $[22,23,57,60,76,85,105,144]$ and also provide information about wetland conditions and health [67, 68, 70,75]. During the last decade, a great deal of studies have addressed a diversity of topics concerning with wetland fish communities including species coexistence and dispersal $[19,21,35,38,56]$, the value of fishes as prey for wetland predators [28,77], effect of wetland connectivity on assemblage composition, nursery value and fisheries harvests $[16,58,63,128,132]$, seasonal use of wetlands as dry-season refugia [123], flooding [34,91], hypoxia [90], responses to human perturbation $[59,114,147]$ and relationship with physicochemical characteristics such as salinity $[77,79,86,92,110]$. The former studies demonstrated that the key roles of wetland fish communities and nature and variability of environmental factors, fish species distributions and community composition [18,67]. The present study was conducted the status of sea bass from Kokko and Kyuntone of The Gulf of Mottama wetland (GoMW) area in Thanatpin Township in Bago Region with the following objectives. Indirect values of fish can support human health [2], connectivity of wetland biodiversity and ecosystem of environment $[2,60,91]$. Bottom temperature, depth, surface temperature, sediment and bottom salinity were most limiting of species habitats of fish in wetlands, in seas and in oceans $[60,115]$. Some fish species are foods of avifauna and fishes are vital connectivity of ecosystem services between biodiversity in wetlands, in coastal regions, in seas, and also in oceans $[81,93,94,125]$. Moreover, fishes of wetlands, rivers, seas, oceans are main economic supports of developing countries and they are valuable natural resources for humans [54, 55, 66]. Due to poor knowledge in conservation, illegal fishing and over fishing daily threaten diversity of fishes. Although, June, July, August are the strictly prohibiting of fishing in Protected Areas (PA), especially, wetlands, the catch weights have still founded at this prohibited time in Myanmar. The analysis of fishing gear is also vial roles for researches of wetland fishes and passive gear and active gear can be found in fishing. Passive gears are necessary the target fishes to enter them and become trapped and active gears can capture fish either by moving faster than fish do or by enclosing fish quickly [67]. The scope of this study recorded the morphometric measurement of sea bass in the study area, observed the catch rate of sea bass and also investigated the prices according to sea bass sizes and value change of sea bass. The correlation between length and weight of sea bass and the utilizing of fishing gear were analyzed in this study. 


\subsection{Background of Study}

Wetland ecosystem and economic valuation can support much benefits to humans and their environment. In Myanmar, conservation of wetlands cannot sustain due to poor environmental conservation knowledge of residents who live near wetland area, insufficient staffs, low budgets and other statements of problems [12]. In wetland areas, trading fishes are becoming first highest earning income, cultivations of paddy, peas and vegetation are second highest earning income and resorts, travel and tours are third highest earning income. During COVID-19 global pandemic periods, the economic status of our world evidently decrease especially aspects of travel and tours. The numbers of ecotourism and local visitors of wetlands have started decreasing since COVID-19 pandemic and then, unfortunately, Myanmar met in political conflicts, income of wetlands are evidently decreasing in travel and tours sessions. However, trading fish can sustain economic valuation of wetland areas and the income of cultivation session of wetlands are decreasing in a just only few numbers. By observing those conditions, trading of fish is key income of wetlands. This study emphasized local income of sea bass and value change in local areas of Myanmar. In the scope of this study, the Gulf of Mottama wetland (GoMW) was chosen and the GoMW is one of most important and unique wetland systems on the world [4, 29, 137]. One of the greatest challenges in wetlands of Myanmar is under threat and pressure by uncoordinated governance and unstainable use of coastal and wetland natural resources, overfishing and habitat destruction of fauna [54, 55]. The Gulf of Mottama (GoM) is situated along Mon State and Bago City and fisheries are primarily fresh water, while coastal fisheries are much more important in Mon State [137]. This study focused on morphological study of sea bass fish and economic value change in local area of Myanmar. By length and body weight of sea bass can generally obtain highest prices and the demands of sea bass in local area are higher more and more and the residents favor the taste of sea bass $[6,8,10,70,115]$. The more abundance populations of sea bass can be found in Kokko and Kyuntone villages than other villages along The Gulf of Mottama Wetland (GoMW). Even if there is no fish trading internationally, the economic valuation of wetland fish trading can support earning for residents of wetland areas and illegal fishing can even be decreased, however, population of people are daily increasing and the demand of fish product can increase relating to human populations and so, the sustainability of biodiversity is necessary to control not to declining of ecosystem services and environmental conservation $[56,57,133]$. Studying of fish can be divided into two categories, (i) quantitative fish sampling method and (ii) qualitative fish sampling method. Quantitative fish sampling methods aim to study measure of fish abundance concerning with relative abundance for communities or mark-recapture estimate for specific taxa, biomass, diversity with inter values concerning with counts and ages, direct measurement of fish concerning with fish length and body weight, habitat characteristics concerning with water temperature, depth of water, inhabiting territorial waters, assemblage, community metrics concerning with indices of diversity, similarity or dissimilarity and ratios concerning with catch-per-unit-effort [67]. Qualitative sampling method targets on fish sex, species lists, descriptions of frequency of occurrence in term of rare uncommon, common and ubiquitous [67]. In this study, data included direct measurements of fish such as fish length and body weight by using quantitative sampling method.

\subsection{The Gulf of Mottama Wetland (GoMW)}

In Myanmar, there are 18 wetland sites as an extraordinary diversity of wetlands such as mountainous wetlands, large freshwater wetlands, lakes to coastal wetlands like as mangroves, mudflats and coral reefs $[25,26]$ and currently 6 wetland sites have been designated as Wetlands of International Importance as Ramsar Sites with a surface area of 278,679 hectares [118-120]. The names of 6 Ramsar Sites are (i) Moe Yun Gyi Wetland Wildlife Sanctuary with an area of 10,359 ha which was designated as Ramsar Sites on 17 November, 2004 and site number was 1431, (ii) Indawgyi Wildlife Sanctuary with an area of 47,884 ha which was designated as Ramsar Sites on 2 February, 2016 and site number was 2256, (iii) Meinmahla Kyun Wildlife Sanctuary with an area of 50,000 ha which was 
designated as Ramsar Sites on 02 February, 2017 and site number was 2280, (iv) The Gulf of Mottama Wetland (GoMW) with an area of 161,03 ha which was designated as Ramsar Sites on 10 May, 2017 and site number was 2299, (v) Inlay lake Ramsar Site with an area of 5,798 ha which was designated as Ramsar Sites on 10 August, 2018 and site number was 2356 and (vi) Nanthar Island And Mayyu Estuary with an area of 3,608 ha which was designated as Ramsar Sites on 22 May , 2020 and site number was 2421 [69, 118-120]. In this study, The GoMW was chosen as research area and the fish with the highest price of local market, sea bass was chosen as study sample. The GoMW is covered by about 150,000 hectares on the boundary areas of Bago Region in the north and Yangon Region in the west and it is also connected to the Bay of Bengal and it is also covered by 45,000 hectares of area within a straight line between the southern point of Pyapon Township in Ayeyarwady Region and the southern point of Mudon Township in Mon State form the mouth of the Sittaung river to the eastern coasts of Kyaikto and Bilin Townships [25, 26, 39, 137]. The GoMW have been designated as East Asian-Australasian Flyway Partnership, (EAAFP) Flyway Network site in 2014 by recognition of its importance for migratory waterbirds. The GoMW is a main migratory stopover as a vitally important habitat for Critically Endangered Spoon-billed Sandpiper, Calidris pygmaea [1, 65, 126] of which there are fewer than 500 populations of the species left on the world $[82,83,103,140,141$, $143,156]$. The GoMW also supports a huge diversity of fish, crustaceans and other fauna and flora and it has already been recognized as a wetland of global significance. The local incorporations of GoMW including with supporting Institutions are (i) Biodiversity and Nature Conservation Association (BANCA), (ii) The Myanmar Fisheries Federation, (iii) Mawlamyine University, (iv) Bago University, (v) Yezin Agriculture University, Local (Non-Government Organizations) NGOs [39.126,137]. The Community-Led Coastal Management in the Gulf of Mottama Project (CLCMGoMP) of the Swiss Agency for Development and Cooperation (SDC) started in April 2018 and extends until December 2021 and the GoMP is being implemented by a consortium comprising HELVETAS Swiss Intercooperation (HELVETAS), the International Union for Conservation of Nature (IUCN) and the Network Activities Group (NAG), and Various International NGOs. The Swiss Agency for Development and Cooperation (SDC), a division of the Federal Department of Foreign Affair (FDFA), is responsible for Switzerland's International cooperation and Development program and SCD in Myanmar aim to carry out gender equality, good governance, climate change and disaster risk reduction and they hope to obtain (i) Employment and Vocational Skill Development, (ii) Agriculture and Food Security, (iii) Health, social services and Local Governance and (iv) Peace, Democratization and Protection. In the Gulf of Mottama Project (CLCMGoMP), the Community-Led Costal Management contributes to SDCs Agriculture and Food Security (AFS) portfolio in 2013-2017 [39] and in April 2018 and extends until December 2021 [126]. The international Universities include as corporation of GoMW, (i) HAFL in Switzerland and (ii) Prince Songkla University in Thailand. Local and International Corporations tend to sustain conservation of the GoMW and GoM management plans [39,126]. The GoM is known as one of the most dynamic estuaries on the world and it is comprising one of the largest areas of mudflats, making it of outstanding global conservation value [25, 26, 117, 154]. About 75,000 hectares are covered with slit and several creeks flow into GoMW and [103, 140, 141, 143, 156] and the GoM has extensive mud flats covering around 4,000 $\mathrm{km}^{2}[127,87]$, the largest mud falt zone in Southeast Asia due to the flow of sediments from four large rivers, the Ayeyarwady, Yangon, Sittaung and Tahnlwin [127] and thus it becomes the largest mud water zone in the world thus, the vast area of silts of GoMW provides livelihoods for residential people. The Gulf exhibits a tidal cycle which is extremely pronounced in speed and volume, gathering from a width of around $100 \mathrm{~km}$ and concentrating in a funnelshaped bay to produce over $3 \mathrm{~m}$ heights on spring tides in the upper estuary and the tide can reach in some places up to $7 \mathrm{~m}$. The GoM is also one of the most extensive and important intertidal ecosystem in the world. The $85 \%$ of residents in GoMW are lower class people and most of them rely on fishery for their daily expenditures and the more international projects in the GoMW, the more job opportunities the residents obtain. 


\subsection{Sustainability of Economic Valuation of Wetland}

In Myanmar, there is very poor in natural resource conservation of wetlands due to low budgets, insufficient staffs, poor techniques, poor environmental conservation knowledge, insufficient local technicians and conservationists. Myanmar has 6 Ramsar sites and among them, the GoMW has many international cooperation to sustain its ecosystem, conservation and economic valuation. Generally, the biodiversity of wetlands is vital for direct economic value of wetlands and they can also support ecosystem services indirectly as indirect economic value $[3,51,52,73,100,102,104]$. There are five capitals of wetland economic valuations, (i) Natural Capital, (ii) Human Capital, (iii) Social Capital, (iv) Financial Capital and (v) Manufactured Capital [68]. Our wetlands is parental supporters for Natural Capital such as cleaning water resource, rice, vegetation, fishes, meats, timbers and places of recreation for human, wildlife habitats and ecosystem services and other useful things of wetland nature for living organisms [54, 55, 67, 88, 99, 134]. Human Capital is divided into three categories (i) Financial makers (ii) conservationists (iii) consumers. These three categories of human capital are vital roles of sustainability of wetlands. Some wetlands in Myanmar have many bad infrastructures and those problems cannot easily to be reformed because of low budgets from Government and insufficient numbers of educated staffs in wetlands $[155,156]$ and other environmental protected area. By unexpected political conflicts of Myanmar in 2021, it will become bad prospects for budgets for environmental conservation in Myanmar. And also, since 2019, our world has faced with dreadful COVID-19 and thus, economic valuation of wetlands in Myanmar have decreased in a few number in international trading of fishes, rice and crops and it has declined in highest number in Eco-tourisms and the other social status has also suffering with bad impacts. Myanmar is necessary to establish rehabilitations in aspects of Nation sovereignty, Economy, Education and Social Status after COVID-19 and local political conflicts and so it will also be difficulty for budgets of wetland conservation and other environmental aspects. However, economic valuation of wetlands can support some people who live near their areas by supporting their basic needs. If human capital can control the sustainability of wetlands' natural capital, the residents are not necessary their daily expenditures even without international trading and Eco-tourisms [66, 116]. The first one of human capital, financial makers in wetlands are owners of resorts, larger scale fishery, small scale fishery, legal timber trading and transporting workers. Depending on Myanmar economic state, small scale fishery in wetlands are $75 \%$ of financial makers and $75 \%$ of residents in wetlands area depend on fishery for their monetary issues. The government tax of wetland resorts, large scale fishery and legal timber trading can support budgets for wetland conservation and small scale fishery can sustain human capitals as basic human resources and transporting workers are attracting human capitals to do more business in wetland areas with comfortable transportation. If human capitals have the sufficient conservation knowledge, human capital can also vice versa support natural capital sustainability and wise use of natural resources in wetlands. The second one of human capital, conservationists are vital for wetlands and they will be from government or some environmental organizations or international environmental organizations or local/international non-government organizations (NGOs). In Myanmar wetlands, the second person of human capital is essential required category for sustainable development of wetlands. The third one of human capital, consumers are plenty numbers and this category aims to local consumers and international consumers. Some people are moving to wetland areas from other places and $90 \%$ of migrant people depend on fishing for their livelihood benefits. Encroaching people has become one of statement of problems for Myanmar wetlands since 10 years ago. Social Capital of wetlands is vital roles for economic valuation of wetland and social capital can lead the improvement of financial capital and human capital and by establishing big social capital, the other capital is ready to sustain their good effects to economic valuation of wetlands. If the four capital are strong in wetlands, manufactured capital can also be ready to sustain economic valuation of wetlands by supporting more financial incomes of residents of wetland area [106]. The big social capital 
such as international investments in wetlands can carry new innovation for economic status of residents of wetland areas including job opportunities for basic class people and also other social capital such as international conservationists and some cooperation of sustainable development programs can share valuable knowledge of wetland conservation and objectives of wise use programs to those residents. The sustainability of five capitals of wetland economic valuation is key for wetlands and they are livelihood benefits of economy and also ecosystem services of wetlands and every conservation perspectives for wetland forest, wetland biodiversity and other natural resources $[3,51,52,73,100,102$, $124,133,159]$. Wetland resort business is one of direct economic value of wetland and it is necessary to improve for foreign currency and bird watching is most popular tourist attraction one in Myanmar and thus, the resort business men should collaborate to conserve biodiversity cycles. The waste of visitors, especially plastic waste is needed to control and systematically throw away. Biodiversity cycles can attractive to local scientific researchers, international scientific researchers and all conservationists and also tourists who want to take recreation. Wetlands are also becoming places to share ethical, cultural, other traditional value, modern techniques, traditional techniques and various educational issues. The following two methods are aiming to sustainability and Development of wetland economic valuation.

\subsubsection{SCIBE - Method}

SCIBE method means that it is a method of sustainable to Capitals and Improving Benefits of Economy. This method is based on five capitals of wetland economic valuation. If natural capital cannot control to conserve, our wetland ecosystem services, economic valuation and all benefited natural machinery will surely disappear. If there is no natural resources, human capital cannot not create social capital, financial capital and manufacture capital [160]. Natural capital and human capital mutually depend on each other and if there is no human capital for natural resources, the nature will give ecosystem services to some living organisms including wildlife, however, just only natural capital cannot create the innovation for our world and the precious benefits of natural resources are fruitless without consumers. Thus, according to our sustainable goals, five capitals need to sustain for economic valuation and for increasing popularity of people, the benefits of economy should try to improve with sustainability of five capitals. This method can provide not only wetland economic valuation but also other aspects of economy.

$$
\text { Possible outcome of EV }=\frac{\text { no.of mothly } / \text { yearly capitals }}{\text { no of typical capitals }} \times 100 \%
$$

Where EV= Economic Valuation, no. of typical capital in the above equation means that number of capitals that cannot have the loss in business of economic valuation.

\subsubsection{EGIETRW - Method}

EGIETRW method means that it is a method of enhancing GROSS Income of EcoTourism by reforming Wetlands. In Myanmar and other developing counties, business sector of Travels and Tours sessions is important one of foreign incomes and it is also important for direct value of wetland economic valuation. Residents of wetland area has used the natural resources of wetlands as their basic jobs before resorts and hotels near wetland regions and thus, social capital cannot use effectively and also manufactured capitals and financial capital flows within the local boundary areas and poor lives of residents could change to middle class and high class. When resorts and hotels have hired some areas of wetland regions, residents of wetland area had a chance to use natural resources of wetlands effectively from some campaigns of environmental conservation, travel costs from visitors, traditional and culture of other different countries, chance of international trading for fishes, home furniture from timber and local tradition utensils. The important problem of wetland in Myanmar is "how to control wastes, especially wastes of plastic bags in wetlands" and they are used to throw the wastes of visitors to wetlands areas, rivers and oceans and this unsystematically waste throwing way can give enormous dan- 
gers to wildlife animals and aquatic animals and even birds and the next problem is encroaching people to wetland boundaries without permission from Government [78] and water restored areas of wetlands are full with encroaching people and in the rainy seasons, wetlands cannot have enough spaces of storage water and waterbirds of wetlands cannot have enough stopovers and the habitats for wetland waterbirds, migratory birds and fishes gradually declined $[1,32,37,61,65]$. For that condition, the numbers of birdwatchers of wetlands will decrease and it directly impact on biodiversity and ecosystem services of wetlands. The bad infrastructures which become from human capital and their wastes is necessary to reform before declining ecosystem services. Good ecosystem services, Healthy Biodiversity, Cleaning surrounding of wetland and Recreation services are key to enhance gross income of wetlands and they can support to earn foreign currency from Eco-tourism sessions.

\subsection{Behaviors and habitats of Sea bass}

A diverse group of common names of sea bass are "Barramundi perch" in Australia, Giant sea perch" in Papua New Guinea, "Sea bass" in South-east Asia and also known as "Ka-kadit" in juvenile state and "Ka-tha- baung" in adult state or in female status in Myanmar [42-49, 121, 129, 157, 158]. The taxonomy of sea bass is complicated by the existence of several nominal species presently relegated to its synonymy [43, 129]. The localities and specimens of sea bass are L. heptadactylus [72, 107], (unknown locality and unknown type), L.vacti $[56,107]$, no types, type locality Ganges River, Bengal, India; L. nobilis $[31,107]$, syntypes frommultiple localities, type locality Pondicherry, India; L. cavifrons $[5,107]$, type lost, type locality "somewhere in Torres Straits or the coast of New Guinea"; and L. darwiniensis [84, 107], type in poor condition, type locality "Darwin, Australia", L calcarifer [13-17, 42, 107, 150, 157, 158], type Lates, type locality "Myanmar and Sri Lanka, from Queensland coast of Australia westwards at least to India [109, 112, 113, 125, 157], from tropical Austria through Indonesia, from Persian Gulf to China, Singapore and Thailand" and L. uwisara [107], type Lates, type locality " Eastern Myanmar" [41-48, 161]. In GoMW area, L. uwisara and L. calcarifer have observed. According to the research of Rohan Pethiyagoda \& Anthony C. Grill (2012), Lates uwisara can be distinguished from L. calcarifer $[107,108,115,142]$ by possessing scales between the base of the third dorsalfin and lateral line; and having a lesser eye diameter of Lates uwisara in 4.4-4.7 \% SL and that of L. calcarifer in $4.8-6.9 \%$ SL.

\subsubsection{Systematic Position of Lates Uwisara}

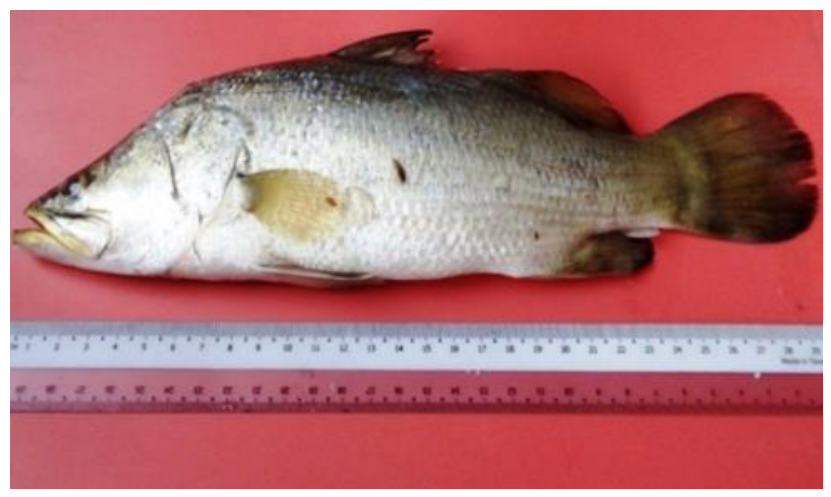

Figure 1. Lates uwisara (Sea bass).

Kingdom
Phylum
Class
Order
Family
Genus

-Animalia

-Chordata

-Actinopterygii

-Perciformes

-Latidae (Lates perches)

-Lates (Cuvier and Valenciennes, 1828) 


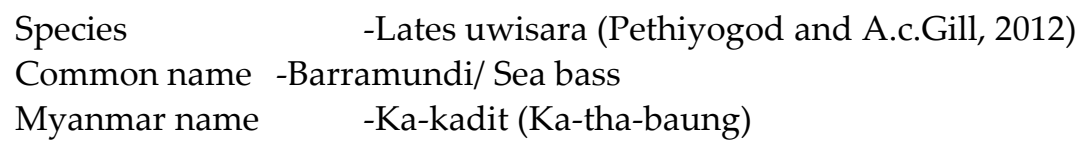

1.4.2. Systematic position of Lates Uwisara

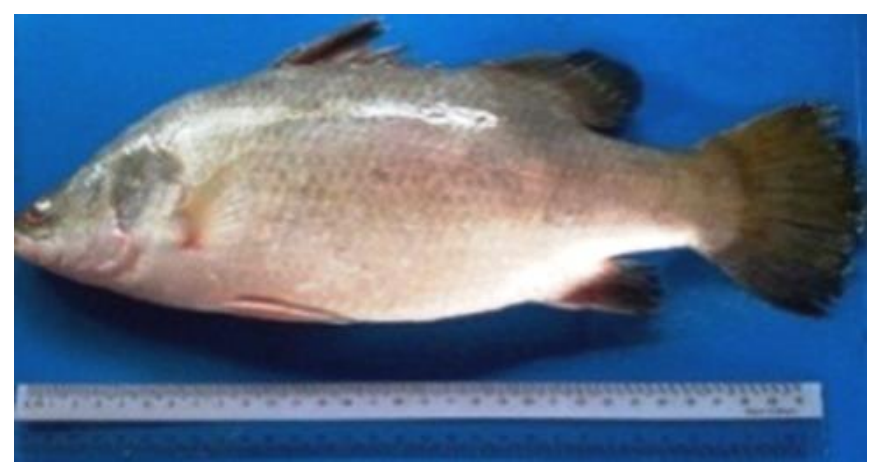

Figure 2. Lates calcarifer (Sea bass).

Kingdom
Phylum
Class
Order
Family
Genus
Species
Common name
Myanmar name
Indonesia name
Oldest name

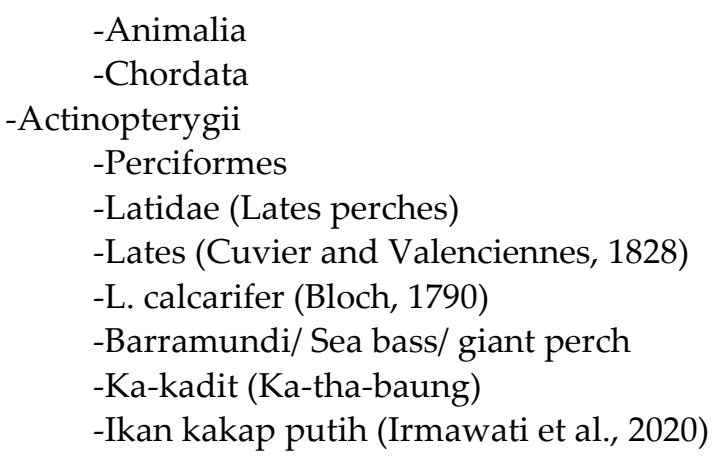

Coiusvacti (Hamilton, 1822)

The representatives of sea bass are catadromous and they are born in sea water and then they spend most of their time in fresh water [10, 18, 95, 96, 150]. Sea bass inhabits freshwater, brackish, marine habitats such as streams, lakes, estuaries and coastal water $[42,62,80,104,128,150,158]$. The newly - hatched larvae are distributed along the coastline of brackishwater estuaries while $1 \mathrm{~cm}$ size larvae can be found in freshwater bodies [11]. Under natural condition, sea bass grows in fresh water and migrates to more saline water for spawning. The sea bass is one of the species with a high potential for cultivation. Sea bass is widely commercial in South East Asia, it is popular marine food fish of high market value and culture of sea bass has been successful in coastal regions in Myanmar $[111,145,146,158]$. Sea bass spawn naturally in captivity [145] and it is used to migrate sea only to breed, a task achieved by its ability to tolerate the complete range of salinities $[95,96]$. Alternatively, sea bass can be induced to spawn by hormonal or environmental manipulations $[49,50,70]$. Smaller fishes of sea bass can be found in rivers and streams and lager fishes in the ocean and estuaries [42,109] and sea bass is dermersal and it is serially hermaphroditic meaning that it can transform from male to female at three to eight years of age [42,53] and its sex ratio is 3.8 males : 1female [42, 53, 95, 96, 109, 148, 149] with males reaching 37 to $72 \mathrm{~cm}$ and then, they are changing into females starting at 73 $\mathrm{cm}$, at around five years, three to five years, or six to eight years depending on the source $[40,53,95,96]$.

\section{Materials and Methods}

\subsection{Study Area}

The present study was conducted from Kokko Tan and Kyuntone villages of Thanatpin Townships in Bago region. These villages are located in the coast of Gulf of Motamma wetland area, Kokko Tan (point 9) is situated between $17^{\circ} 12^{\prime} 16.38^{\prime \prime} \mathrm{N}$ and $96^{\circ}$ 
$47^{\prime} 23.82^{\prime \prime} \mathrm{E}$, Kyuntone (point 10) is $17^{\circ} 12^{\prime} 35.76^{\prime \prime} \mathrm{N}$ and $96^{\circ} 48^{\prime} 2,64^{\prime \prime} \mathrm{E}$. The following figure (3) shows the population of Kokko Tan Village and Kyuntone village. According to the result of this study $75 \%$ of household are working fishery in Kokko village but Kyuntone village is far from Sittaung river banks in GoMW and they depend on three artificial lakes for fishery and just only $30 \%$ of household are working fishery. In the two study areas of this research, sea bass trading is one of the important commercial roles and farming is followed by fishery.
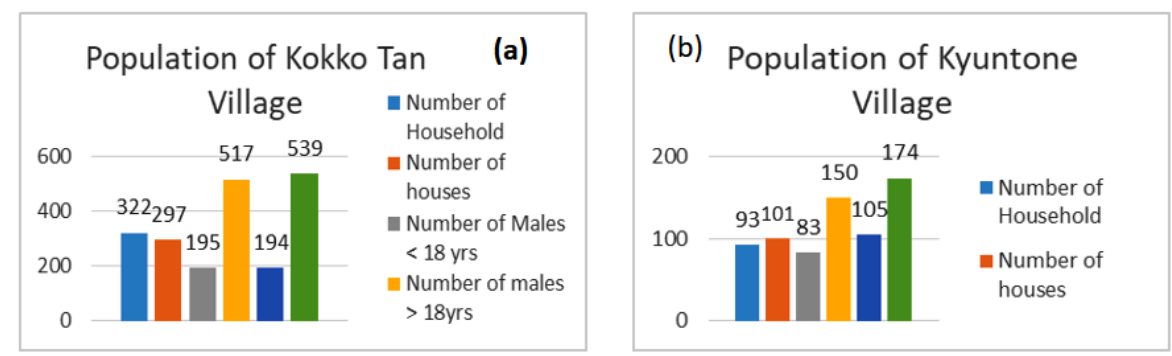

Figure 3. (a) Population of Kokko Tan Village and (b) Kyuntone Village.

\subsection{Study Period}

Study period was lasted from September 2019 to August 2020.

\subsection{Method}

Fifty Specimens were randomly collected and measured total length, standard length and body weight from Kokko Tan and Kyuntone villages by monthly. Invoice of sea bass were collected monthly from the depot and fish sellers of two study area. Collected data were entered into micro-soft excel for calculations and analyzed. Data is presented in the following section using photographs, table, graph and histogram. And then the data of two study areas were compared and discussed.

\section{Results}
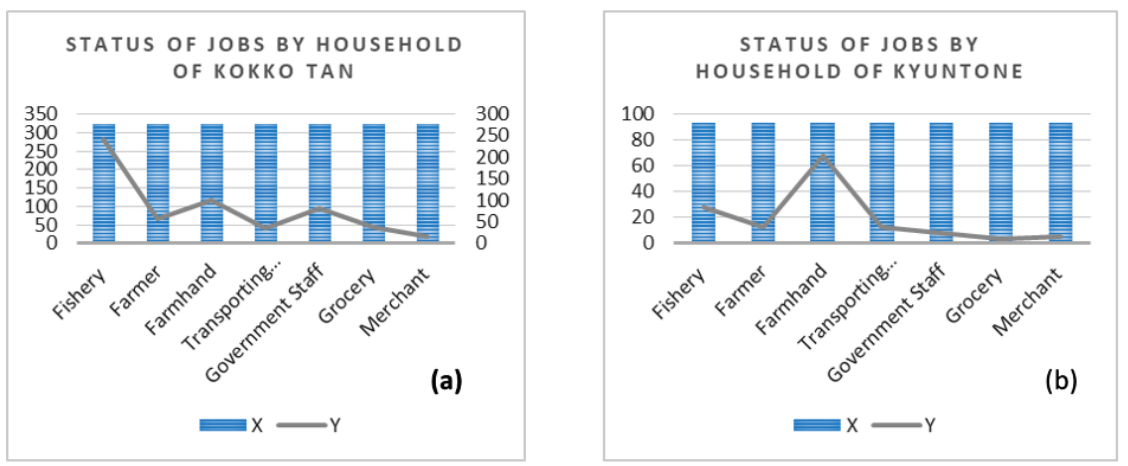

Figure 4. Job status of Kokko Tan village and Kyuntone village by household.

Figure (4) shows the job status of Kokko Tan village according to number of household. The villagers of Kokko Tan villages are relying on fishery and fishery is the main commercial status of Kokko Tan village and farming followed after fishery. However, farming is the first important commercial status for villagers and fishery is second commercial status in Kyuntone villages. 

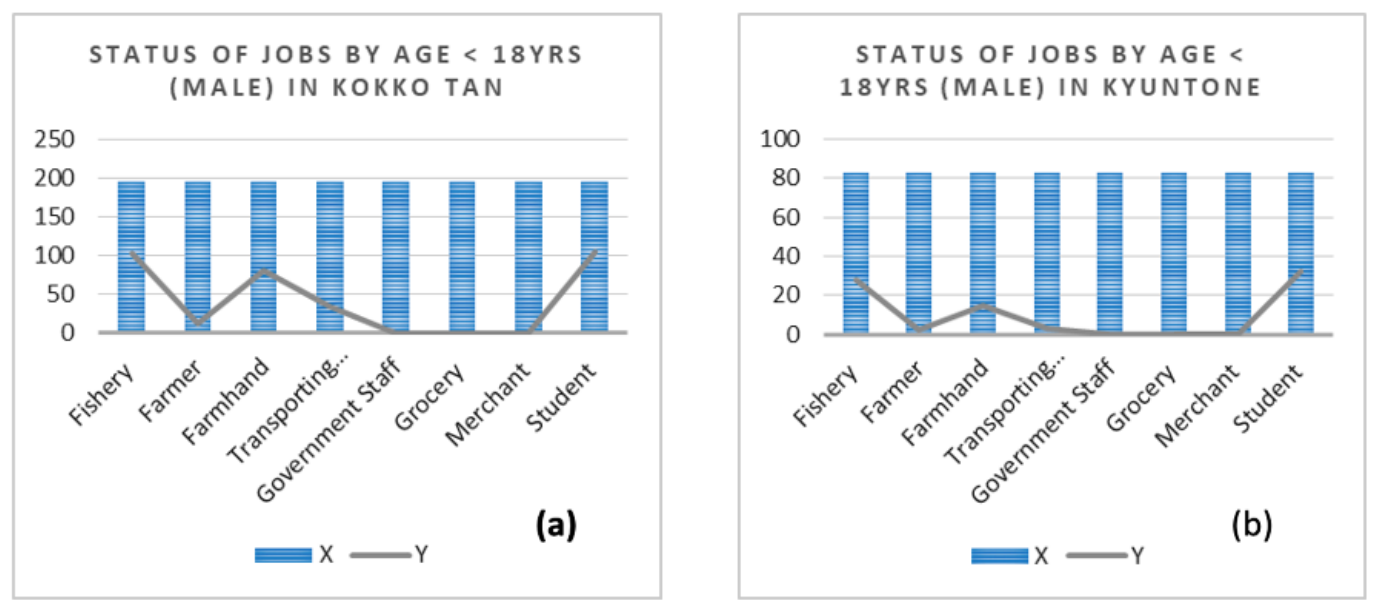

Figure 5. Job status of Kokko Tan village and Kyuntone village by age under 18 years (male).

Figure (5) shows the job status of Kokko Tan village according to number of male under 18 years old. In the total amount of 195 people of Kokko Tan village, 102 people are working fishery, 12 people have their own farm land and paddy fields, 80 people are farmhands, 35 people are transporting workers and 105 people are students and, in Kyuntone village, in the total amount of 83 people, 28 people are working fishery, 2 people have their own farm land and paddy fields, 15 people are farmhands, 3 people are transporting workers and 32 people are students.
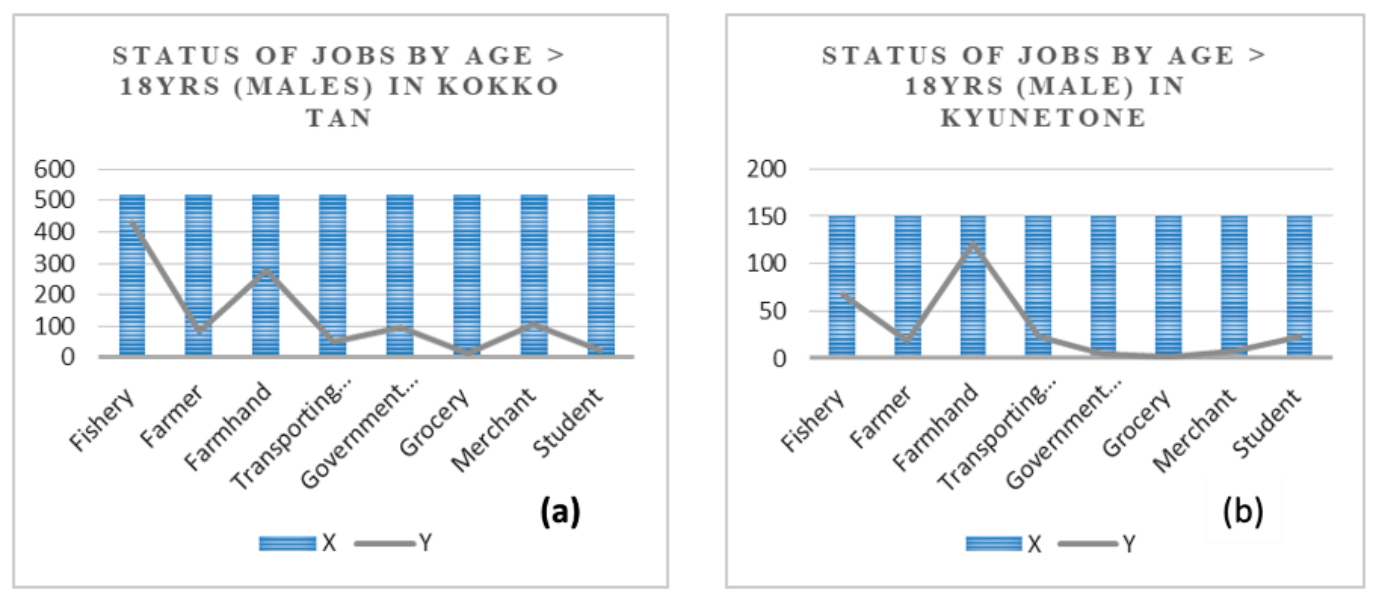

Figure 6. Job status of Kokko Tan village and Kyuntone village by age above 18 years (male).

Figure (6) shows the job status of Kokko Tan village according to number of male under 18 years old. In the total amount of 517 people of Kokko Tan village, 428 people are working fishery, 80 people have their own farm land and paddy fields, 278 people are farmhands, 50 people are transporting workers, 96 people are government staffs, 12 people are grocery owners, 103 are merchants, 23 are students and in the total amount of 517 people of Kyuntone village, 67 people are working fishery, 18 people have their own farm land and paddy fields, 121 people are farmhands, 23 people are transporting workers, 52 people are government staffs, 7 people are grocery owners, 7 are merchants and 23 are students. 


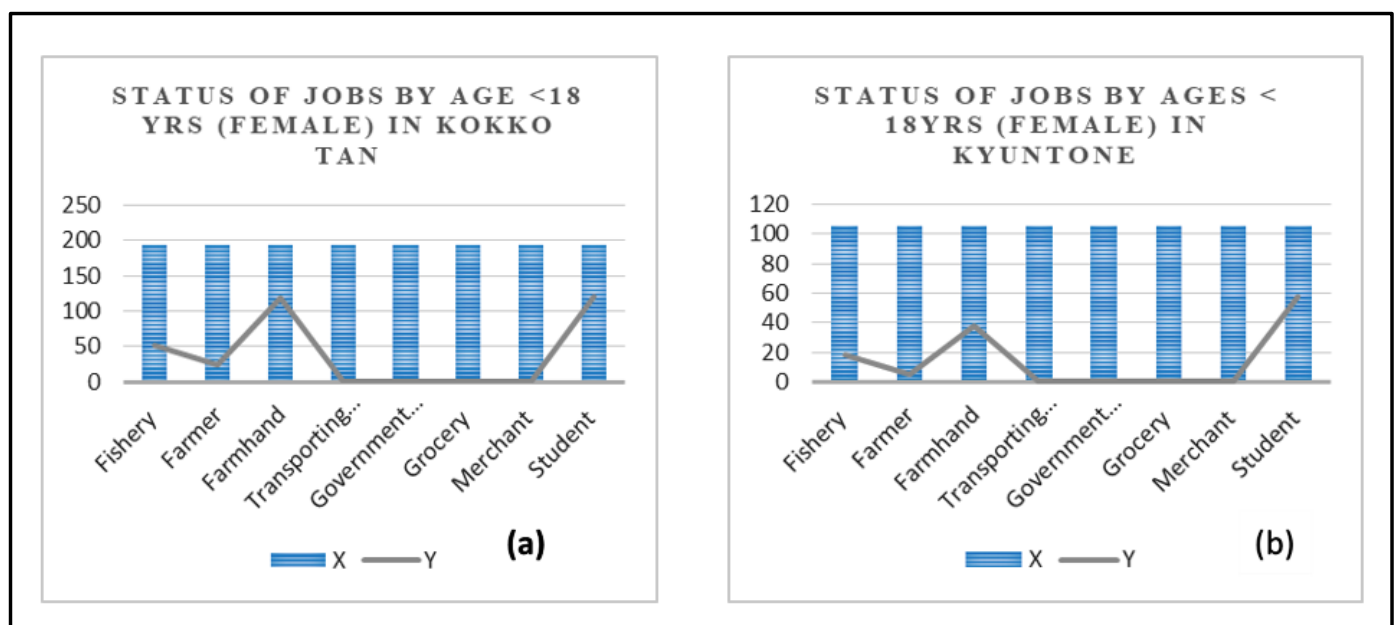

Figure 7. Job status of Kokko Tan village and Kyuntone village by age under 18 years (female).

Figure (7) shows the job status of Kokko Tan village according to number of male under 18 years old. In the total amount of 194 people of Kokko Tan village, 52 people are working fishery, 23 people have their own farm land and paddy fields, 118 people are farmhands, and 121 people are students and, in Kyuntone village, in the total amount of 105 people, 18 people are working fishery, 5 people have their own farm land and paddy fields, 38 people are farmhands and 58 people are students.
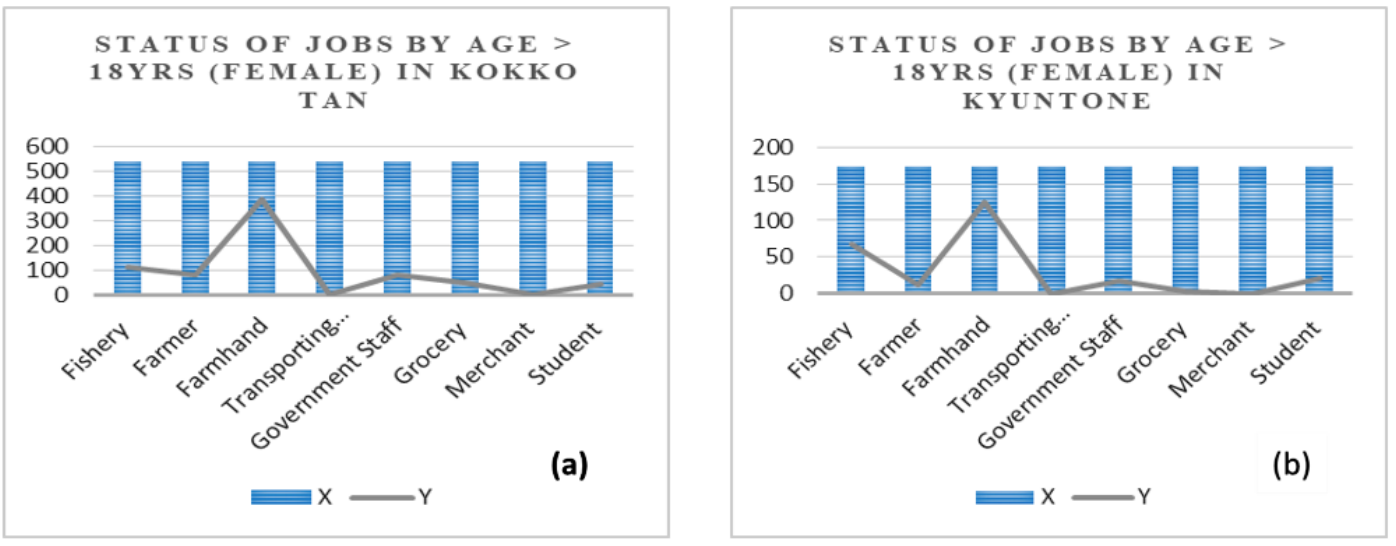

Figure 8. Job status of Kokko Tan village and Kyuntone village by age above 18 years (female).

Figure (8) shows the job status of Kokko Tan village according to number of male under 18 year old. In the total amount of 539 people of Kokko Tan village, 112 people are working fishery, 78 people have their own farm land and paddy fields, 384 people are farmhands, 80 people are government staffs, 48 people are grocery owners, 3 are merchants, 45 are students and in the total amount of 174 people of Kyuntone village, 68 people are working fishery, 12 people have their own farm land and paddy fields, 125 people are farmhands, 8 people are government staffs, 3 people are grocery owners and 21 are students. According to figure (2), (3), (4), (5) and (6), fishery is the main commercial status in Kokko Tan village and cultivation in farmlands is second one and in Kyunetone, cultivation in farmlands is first role of commercial status and fishery is second one. By this result, some villagers are not only transporting workers and but also farmhands, some are not only fishermen and but also farmhands, some are not only students but also fishermen and some are not only students but also farmhand because of low income of their family.

Table 1. Size range $(\mathrm{cm})$ of sea bass in Kokko Tan and Kyuntone during the study period.

\begin{tabular}{ccccccccccc}
\hline Cm & $\mathbf{7 - 1 1}$ & $\mathbf{1 1 . 1 - 1 5}$ & $\mathbf{1 5 . 1 - 1 9}$ & $\mathbf{1 9 . 1 - 2 3}$ & $\mathbf{2 3 . 1 - 2 7}$ & $\mathbf{2 7 . 1 - 3 1}$ & $\mathbf{3 1 . 1}-\mathbf{3 5}$ & $\mathbf{3 5 . 1 - 3 9}$ & $\mathbf{3 9 . 1 - 4 3}$ & $\mathbf{4 3 . 1 - 4 7}$ \\
\hline Kokko Tan & 19 & 5 & 49 & 79 & 50 & 138 & 37 & 3 & 0 & 0
\end{tabular}




\begin{tabular}{lllllllllll} 
Kyuntone & 15 & 4 & 39 & 89 & 78 & 70 & 33 & 32 & 3 & 2 \\
\hline
\end{tabular}

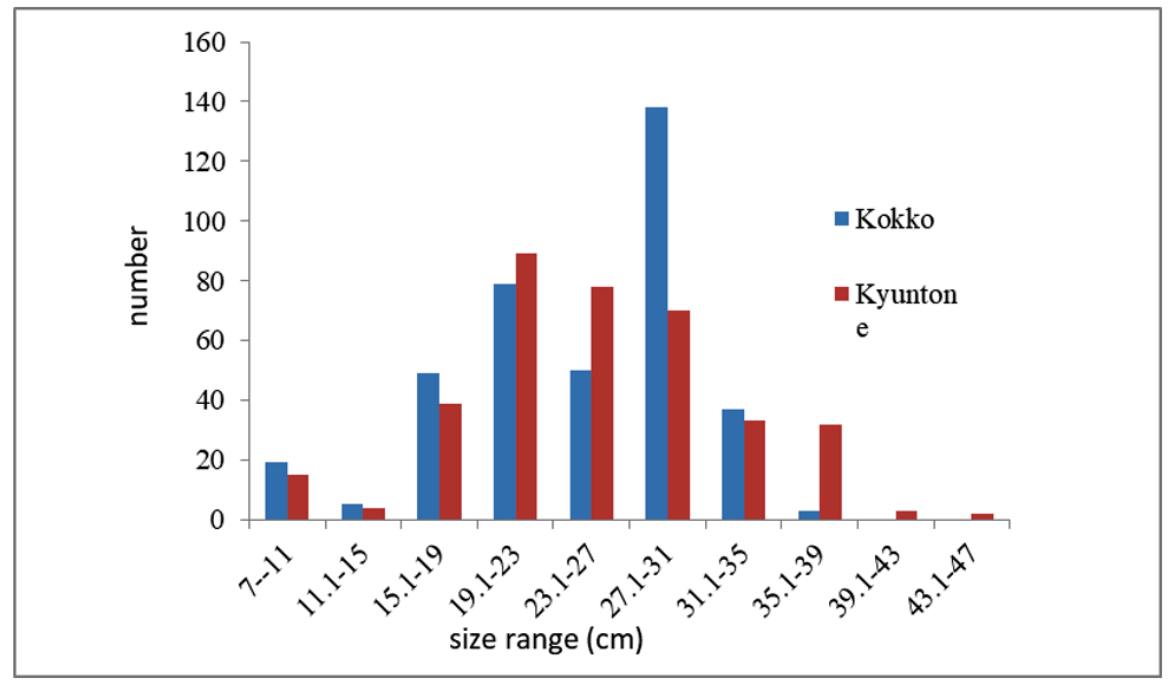

Figure 9. Comparison of size range of Sea bass between Kokko Tan and Kyuntone.

Table (1) and figure (9) show the standard length frequencies of sea bass sample at the two villages. In general, the sizes are similar with the exception of the 27.1-31 category where the fish landed at Kokko were almost double the number at Kyuntone, and Kyuntone had more fish in the 35.1-39 category and a few large fish in the $39-47 \mathrm{~cm}$, that will not found at Kokko Tan.

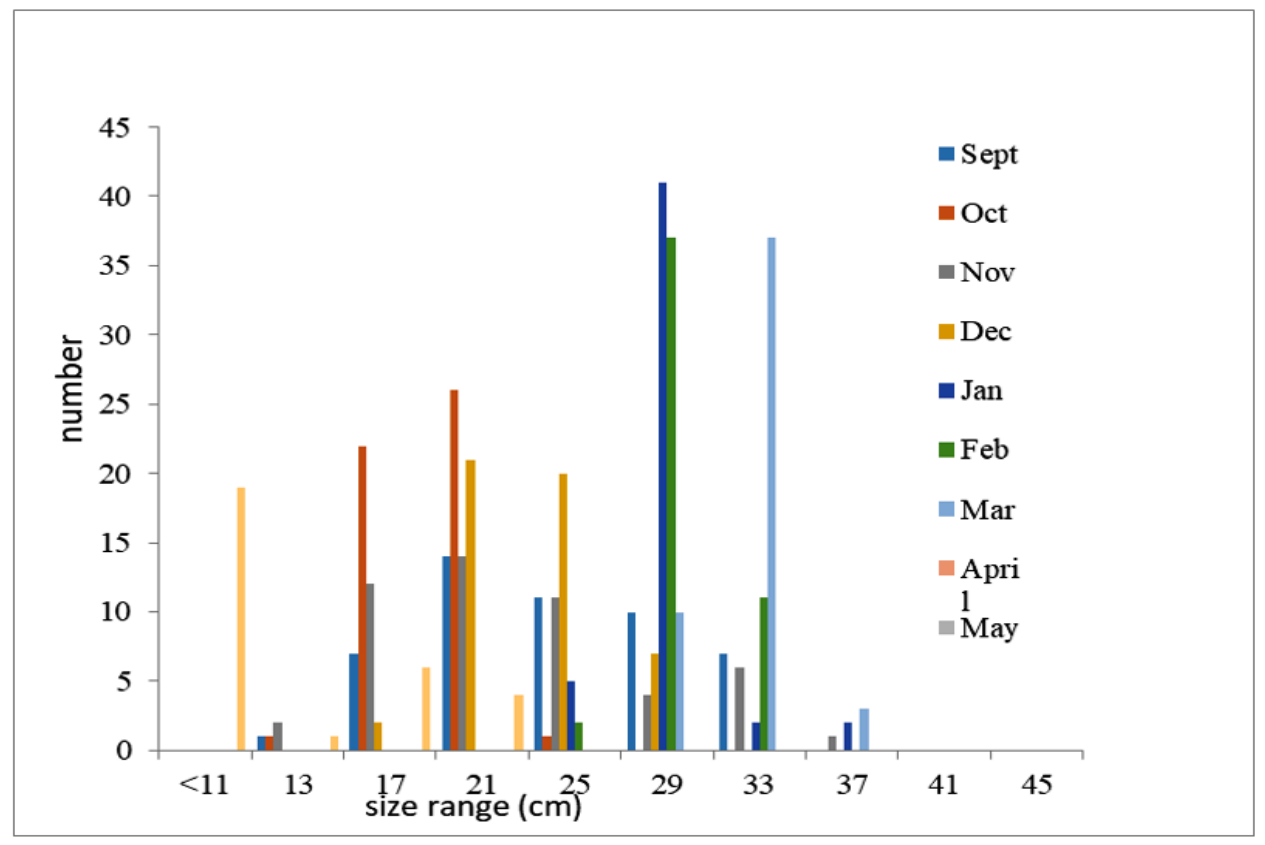

Figure 10. Comparison of size range of Sea bass in Kokko Tan by month. 


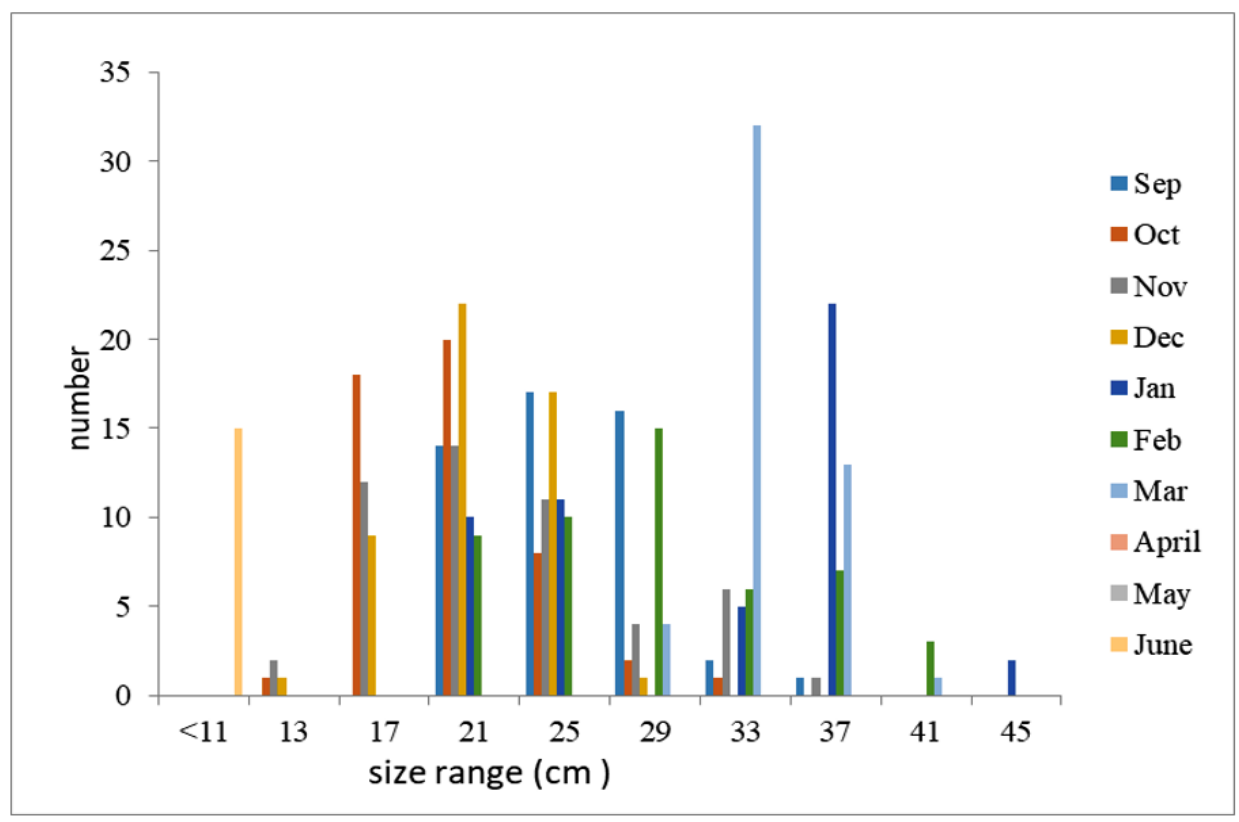

Figure 11. Comparison of size range of Sea bass in Kyuntone by month.

Figure $(10,11)$ indicate that only in June were smal sizes $<11 \mathrm{~cm}$ (SL) found, while no fish were landed during April and May. Larger sized fish in the 29 size category where found in larger number in January \& February in Kokko Tan and during March at both villages. The largest number of fish in the $33 \mathrm{~cm}$ category was in Kyuntone in January to March while very few were found in Kokko. Fish $>35 \mathrm{~cm}$ were found in Kyuntone during January to March, while only a very few where found in Kokko Tan. The largest sizes $41 \mathrm{~cm}$ and $45 \mathrm{~cm}$ were not found at Kokko Tan.

Table 2. Monthly mean value of standard length and body weight of sea bass at Kokko and Kyuntone.

\begin{tabular}{|c|c|c|c|c|c|c|}
\hline & KK & KK & KK & $\mathrm{KT}$ & $\mathrm{KT}$ & KT \\
\hline Month & $\begin{array}{r}\mathrm{TL} \\
(\mathrm{Mean} \pm \mathrm{SD})\end{array}$ & $\begin{array}{c}\text { SL } \\
(\text { Mean } \pm S D)\end{array}$ & $\begin{array}{c}\mathrm{BW}(\mathrm{g}) \\
(\mathrm{mean} \pm \mathrm{SD})\end{array}$ & $\begin{array}{c}\text { TL } \\
(\text { Mean } \pm \text { SD) }\end{array}$ & $\begin{array}{c}\text { SL } \\
(\text { Mean } \pm S D)\end{array}$ & $\begin{array}{c}\mathrm{BW}(\mathrm{g}) \\
(\mathrm{mean} \pm \mathrm{SD})\end{array}$ \\
\hline Sep & $29.55 \pm 6.6$ & $25.04 \pm 5.31$ & $428.7 \pm 278.09$ & $29.68 \pm 3.95$ & $26.24 \pm 3.65$ & $389.98 \pm 175.3$ \\
\hline Oct & $22.5 \pm 2.13$ & $19.43 \pm 2.07$ & $180.1 \pm 44.23$ & $24.39 \pm 4.07$ & $20.83 \pm 3.63$ & $237 \pm 146.88$ \\
\hline Nov & $26.87 \pm 6.44$ & $23.41 \pm 5.71$ & $352.1 \pm 255.41$ & $26.85 \pm 6.45$ & $23.41 \pm 5.71$ & $339.3 \pm 239.73$ \\
\hline Dec & $27.09 \pm 3.37$ & $23.72 \pm 3.13$ & $279.42 \pm 95.45$ & $25.12 \pm 3.75$ & $21.74 \pm 3.40$ & $231.6 \pm 100.44$ \\
\hline Jan & $33.22 \pm 2.32$ & $28.92 \pm 2.04$ & $584.26 \pm 116.69$ & $35.93 \pm 8.00$ & $31.39 \pm 7.16$ & $644.58 \pm 380.48$ \\
\hline Feb & $34.99 \pm 2.21$ & $30.02 \pm 1.81$ & $655.16 \pm 132.03$ & $34.08 \pm 5.85$ & $29.4 \pm 5.54$ & $630.32 \pm 319.16$ \\
\hline Mar & $35.43 \pm 2.96$ & $32.70 \pm 1.58$ & $660.7 \pm 112.23$ & $35.26 \pm 2.56$ & $29.93 \pm 2.18$ & $963.24 \pm 280.86$ \\
\hline June & $14.64 \pm 5.73$ & $12.62 \pm 4.78$ & $87.33 \pm 66.62$ & $10.32 \pm 0.93$ & $9.07 \pm 0.85$ & $43.97 \pm 16.66$ \\
\hline
\end{tabular}



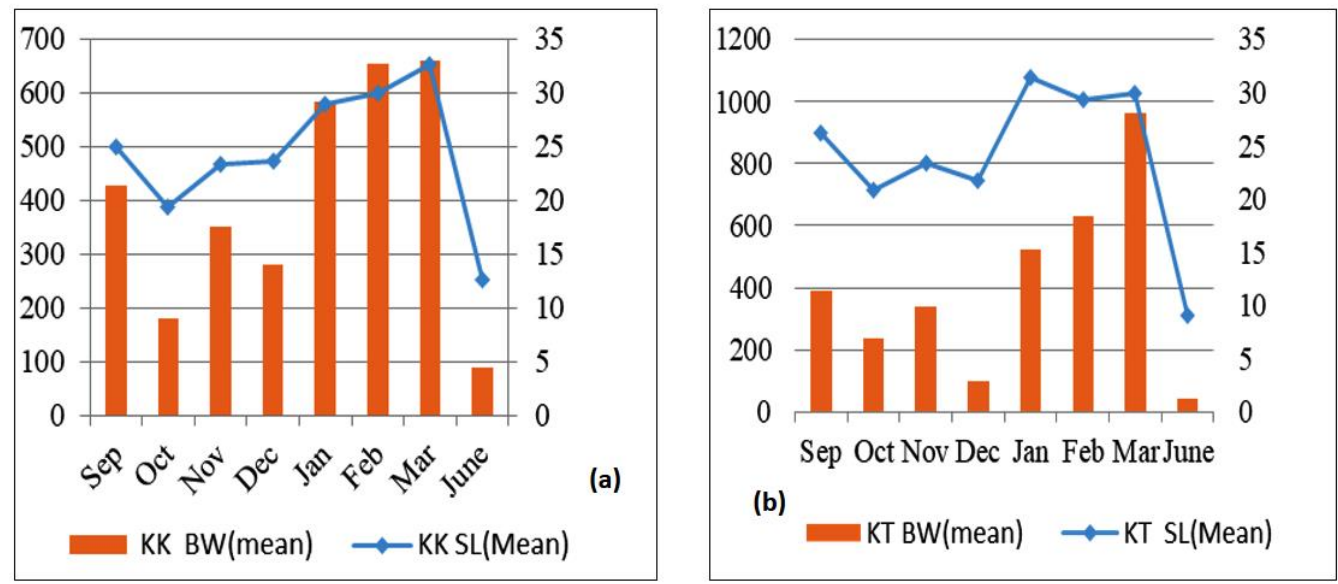

Figure 12. Relation of standard length and body weight in Kokko Tan and Kyuntone.

In Kokko Tan, mean value of standard length and body weight were highest in March $(32.70 \pm 1.58,660.7 \pm 112.23)$ and followed by February $(30.02 \pm 1.81,660.7 \pm 112.23)$ and January $(28.92 \pm 2.04,584.26 \pm 116.69)$. In Kyuntone, mean value of standard length was peak in January (31.39 \pm 7.16$)$. February (29.4 \pm 5.54$)$ and March (29.93 \pm 2.18$)$ were higher than the other months but mean value of body weight were peak in March (963.24 \pm 280.86$)$. January (644.58 \pm 380.48$)$ and February $(630.32 \pm 319.16)$ were higher than the other month. The lowest mean value of standard length and body weight were found in June $(12.62 \pm 4.78$, $87.33 \pm 66.62),(9.07 \pm 0.85,43.97 \pm 16.66)$ at both study areas (Table 2, Figure 12).

Table 3. Monthly catch weight of Sea bass in Kokko Tan and Kyuntone.

\begin{tabular}{ccc}
\hline Months & Kokko Tan Total sum $\mathbf{( K g )}$ & Kyuntone Total sum $\mathbf{( K g )}$ \\
\hline August & 171.67 & 197.08 \\
September & 255.79 & 267.12 \\
October & 829.92 & 339.12 \\
November & 191.92 & 119.15 \\
December & 100.54 & 403.6 \\
January & 50.46 & 159.15 \\
February & 65.58 & 127.04 \\
March & 22.4 & 48.52 \\
\hline
\end{tabular}

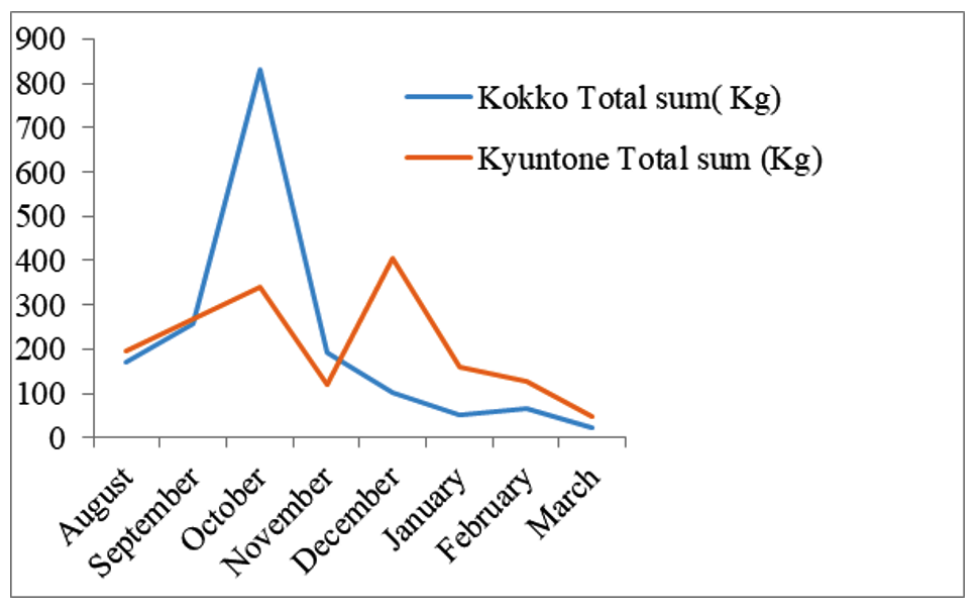

Figure 13. Total catch weight of Kokko Tan and Kyuntone.

Specimens were not found in April and May. Because all channel, creek and wild pond had no water and dried. Some local fishermen told that they caught very small fry specimen from the sea in these month. But, very small specimens were recorded in June. 
According to the invoice data, monthly catch weight of sea bass is most abundance in October (829.62) kg in Kokko Tan and (339.12) kg in Kyuntone. The lowest catch weight of sea bass in March (22.4) kg in Kokko Tan and (48.52) kg in Kyuntone (Table 3, Figure 13).

Table 4. Monthly recorded catch weight $(\mathrm{kg})$ by size groups at Kokko Tan and Kyuntone.

\begin{tabular}{ccccccc}
\hline Month & A(large) & $\begin{array}{c}\text { Kokko Tan } \\
\text { B(Medium) }\end{array}$ & C(Small) & A(large) & $\begin{array}{c}\text { Kyuntone } \\
\text { B(Medium) }\end{array}$ & C(Small) \\
\hline August & 65.85 & 66.15 & 39.62 & 84.12 & 75.98 & 36.99 \\
September & 66.69 & 110.13 & 78.97 & 44.44 & 121.38 & 101.29 \\
October & 125.08 & 269.77 & 435.08 & 68.96 & 145.46 & 124.7 \\
November & 65.96 & 71.15 & 58.62 & 24.93 & 52.38 & 41.85 \\
December & 22.13 & 33.23 & 45.08 & 80.77 & 136.77 & 186.06 \\
January & 10.85 & 17.23 & 22.38 & 42.62 & 66.08 & 45.08 \\
February & 35.43 & 18.6 & 11.55 & 46.04 & 45.54 & 35.46 \\
March & 11.85 & 8.6 & 1.95 & 11.51 & 32.42 & 4.59 \\
Total & 403.84 & 594.86 & 693.25 & 403.39 & 676.01 & 576.02 \\
\hline \multicolumn{7}{c}{}
\end{tabular}
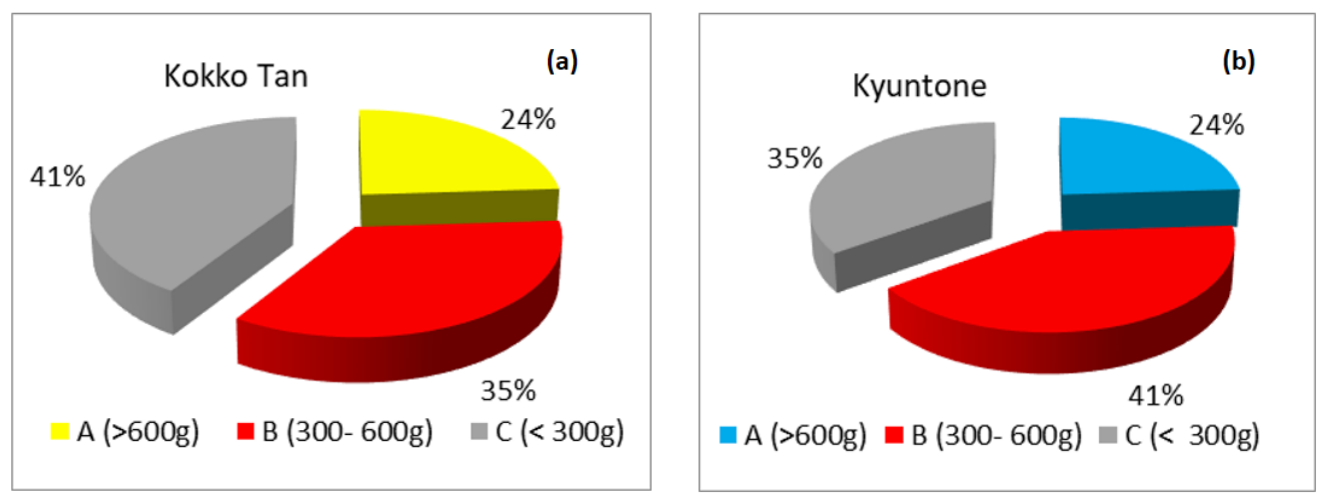

Figure 14. Percentage of Size Groups in Kokko Tan and Kyuntone.

According to the invoice, catch weight by price size were classified into Large (A>600g), Medium (B 300-600g), Small (C<300). Based on the price size, price group small (C) was most abundance in Kokko Tan 41\% and followed by medium (B) 35\% and large (A) $24 \%$. All price size groups were most abundance in October at Kokko Tan. Although price group (B) was most abundance $41 \%$ and followed by size group small (C) $35 \%$ and size group (24) 28\% in Kyuntone. Price group (A) and (B) were more abundance in October; price group $(\mathrm{C})$ was more abundance in January (Table 4, Figure 14).

Table 5. Monthly price size group (MMK/kg) of Sea bass in Kokko Tan and Kyuntone.

\begin{tabular}{ccccccc}
\hline Months & \multicolumn{3}{c}{ Kokko Tan } & Kyuntone \\
& A(Large) & B(Medium) & C(Small) & A(Large) & B(Medium) & C(Small) \\
\hline August & 5930 & 4422.5 & 3236.32 & 4940 & 3855.17 & 3099.69 \\
September & 5228.26 & 3789.26 & 2693.89 & 5066.9 & 4074.47 & 3254.06 \\
October & 4296.72 & 3224.67 & 2441.11 & 4056 & 3405 & 2511.36 \\
November & 4474.17 & 3410.79 & 2739.29 & 3705 & 2502.5 & 1755 \\
December & 4571.67 & 3778.13 & 2949.38 & 4416.18 & 3791.67 & 3460.3 \\
January & 4940 & 4069 & 3129.29 & 5107.14 & 4242.73 & 3788.57 \\
February & 6229.17 & 5362.5 & 4503.57 & 5158.64 & 4468.75 & 3900 \\
March & 6825 & 5958.33 & 4875 & 7280 & 6120.83 & 5281.25 \\
\hline
\end{tabular}



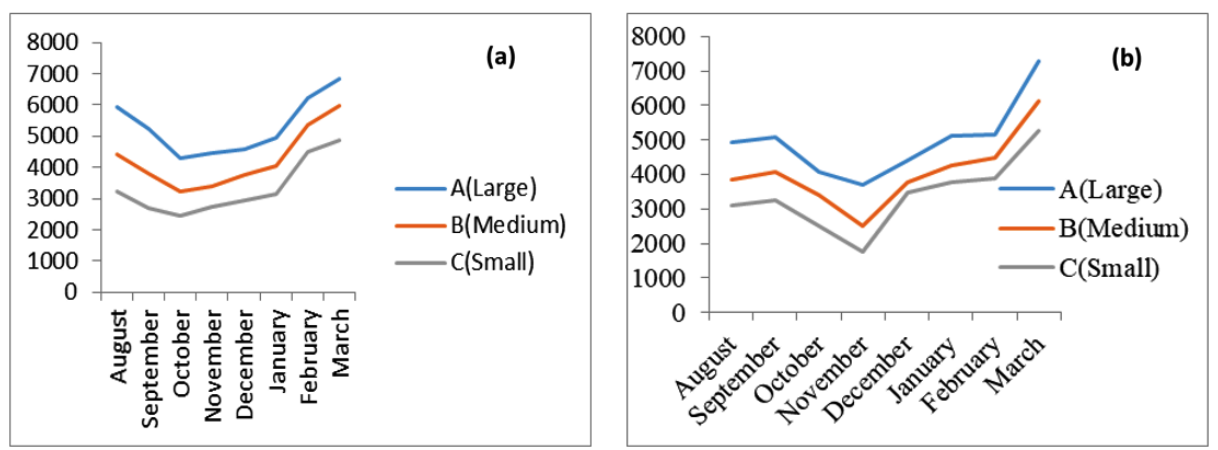

Figure 15. Relation of price sizes in sea bass at Kokko Tan and Kyuntone.

According to the recorded data, prices relation to all size groups $A, B, C$ were highest in March (6825, 5958.33,48750 ) MMK/kg in Kokko Tan and (7280, 6120, 5281.25 MMK/kg in Kyuntone. Lowest price of A, B, C were observed in October $(4296.72,3224.67,2441.11)$ $\mathrm{MMK} / \mathrm{kg}$ in Kokko Tan and $(3075,2502.5,1755) \mathrm{MMK} / \mathrm{kg}$ in November respectively. Price sizes of Kokko Tan and Kyuntone were fluctuated for every month. Specimens were not landed in April and May. Very small specimens were often observed with tides informed by local fisherman in these months. In June, young specimens were very rarely seen in both study sites and no invoice was got until June (Table 5, Figure 15).

According to the recorded data, prices relation to all size groups A (A>500g), B(200$500 \mathrm{~g}), \mathrm{C}(\mathrm{C}<200 \mathrm{~g})$ were highest in March $(6825,5958.33,48750) \mathrm{MMK} / \mathrm{kg}$ in Kokko Tan and (7280, 6120, 5281.25) MMK/kg in Kyuntone. Lowest price of A, B, C were observed in October $(4296.72,3224.67,2441.11) \mathrm{MMK} / \mathrm{kg}$ in Kokko Tan and $(3075,2502.5,1755) \mathrm{MMK} / \mathrm{kg}$ in November respectively. Price sizes of Kokko Tan and Kyuntone were fluctuated for every month. Specimens were not landed in April and May. Very small specimens were often observed with tides informed by local fishermen in these months. In June, young specimens were very rarely seen in both study sites and no invoice was got until June (Table 5, Figure 15).

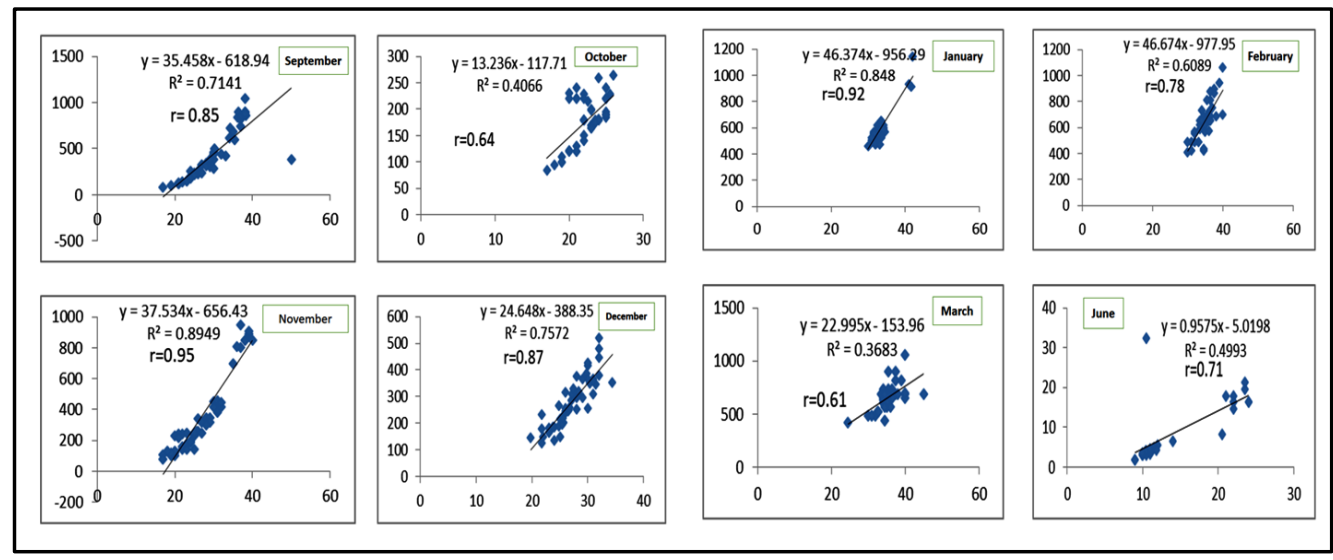

Figure 16. Relation between total length and body weight of sea bass in Kyuntone. 


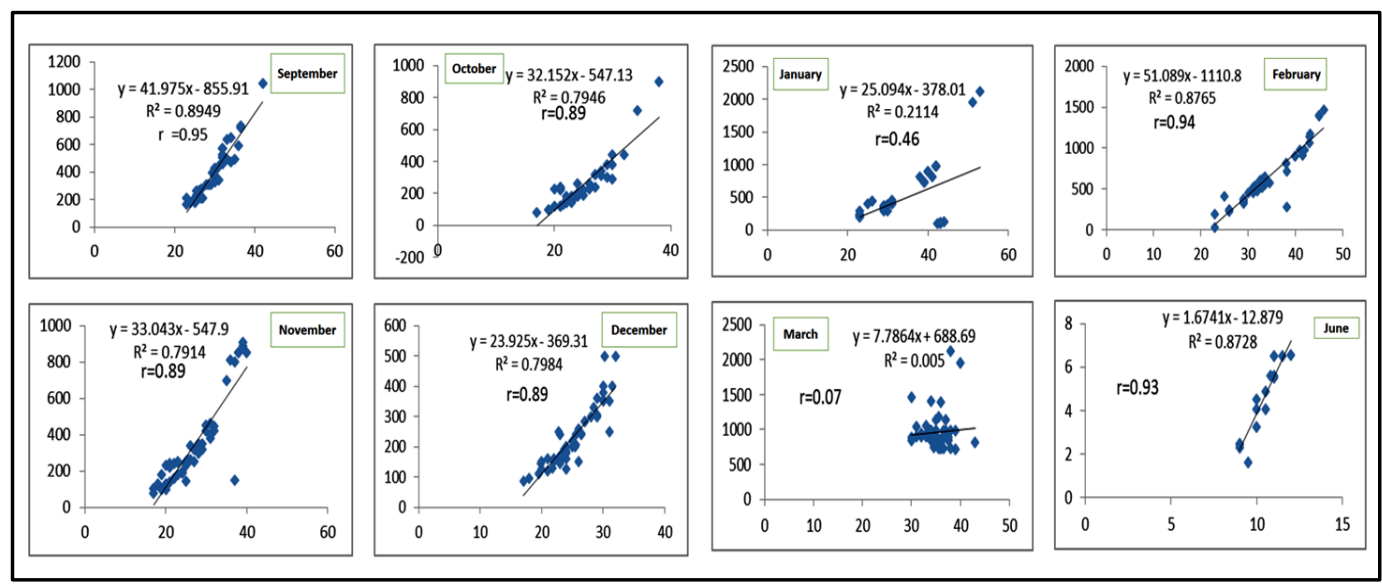

Figure 17. Relation between total length and body weight of sea bass in Kokko Tan.

Table 6. Correlation coefficient of sea bass in Kokko Tan and Kyuntone.

\begin{tabular}{ccccc}
\hline Months & $\begin{array}{c}\text { KK } \\
\text { Coefficient of deter-Coefficient of corre- } \\
\text { mination }\end{array}$ & $\begin{array}{c}\text { KT } \\
\text { lation }\end{array}$ & $\begin{array}{c}\text { Coefficient } \\
\text { of determination }\end{array}$ & $\begin{array}{c}\text { Coefficient of } \\
\text { correlation }\end{array}$ \\
\hline Sept & 0.71 & 0.85 & 0.89 & 0.95 \\
Oct & 0.41 & 0.64 & 0.79 & 0.89 \\
Nov & 0.89 & 0.95 & 0.79 & 0.89 \\
Dec & 0.76 & 0.87 & 0.79 & 0.89 \\
Jan & 0.84 & 0.92 & 0.21 & 0.46 \\
Feb & 0.61 & 0.78 & 0.81 & 0.94 \\
March & 0.37 & 0.61 & 0.01 & 0.07 \\
June & 0.50 & 0.71 & 0.87 & 0.93 \\
\hline
\end{tabular}

The length weight relationship of sea bass in Kokko Tan of September, October, November, December, January, February, March and June revealed the coefficient of determination $\left(\mathrm{R}^{2}\right)$ were $(0.71),(0.41),(0.89),(0.76),(0.84),(0.61),(0.37)$ and $(0.50)$ with the coefficient of correlation (r) were (0.85), (0.64), (0.95), (0.87), (0.92), (0.78), (0.61) and (0.71). Therefore, September, November, December, January, February were strong positive correlation and October, March and June were moderately positive correlation between length and body weight of sea bass (Table 6 and Figure 16).

In Kyuntone, length weight relationship of sea bass in September, October, November, December, January, February, March and June revealed the coefficient of determination $\left(\mathrm{R}^{2}\right)$ were $(0.89),(0.79),(0.79),(0.79),(0.21),(0.88),(0.01)$ and $(0.87)$ with the coefficient of correlation (r)were (0.95), (0.89), (0.89), (0.89), (0.46), (0.94), (0.07) and (0.93). So, September, October, November, December, February and June were strong positively correlated. January was moderately positive correlation and March was very weak positively correlated (Table 6 and Figure 17). 


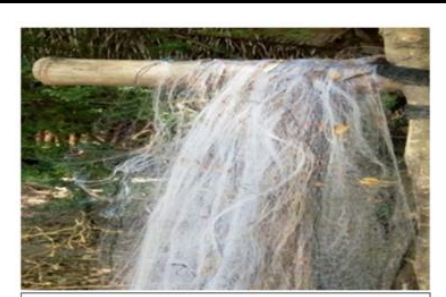

A. Set gill net ( Tar pike)

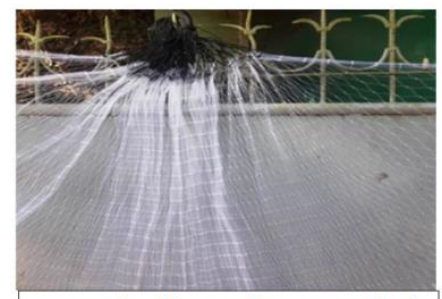

B. Drift gill net (Hmaw pike)

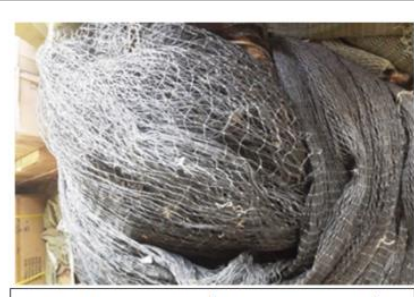

C. Stow net (Kyar pa zat)

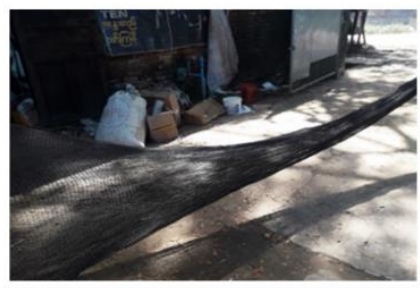

D. Gill net (swae pike)

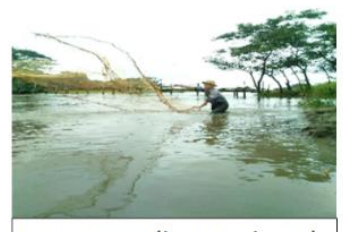

E. Cast net (lat pyit kyun)

Figure 18. Utilizing fishing gear of sea bass in study areas.

In figure (18), utilize fishing gear of sea bass in both villages were stow net (Kyar pa zat pike) with $5-15 \mathrm{~cm}$, set gill net (Tar pike) with $5-12.5 \mathrm{~cm}$, drift gill net (Hmaw pike) $5-12.5 \mathrm{~cm}$, cast net (lat pyit kyun) $2.2-5.5 \mathrm{~cm}$ of raining season (June - August). In cold season of (Sept - Dec) utilize the gill net (swae pike) $5-15 \mathrm{~cm}$. In dry season, fisher were moved to the joint area of Sittaung river and in the shallow water of near the Gulf area utilize fishing gear are depend on the water level such as cast net (lat pyit kyun) 2.2 - 5.5 $\mathrm{cm}$ and set gill net (Tar pike) with $5-12.5 \mathrm{~cm}$, gill net (swae pike) $5-15 \mathrm{~cm}$ (Fig. 18).

\subsection{Sea bass trading and value chain}

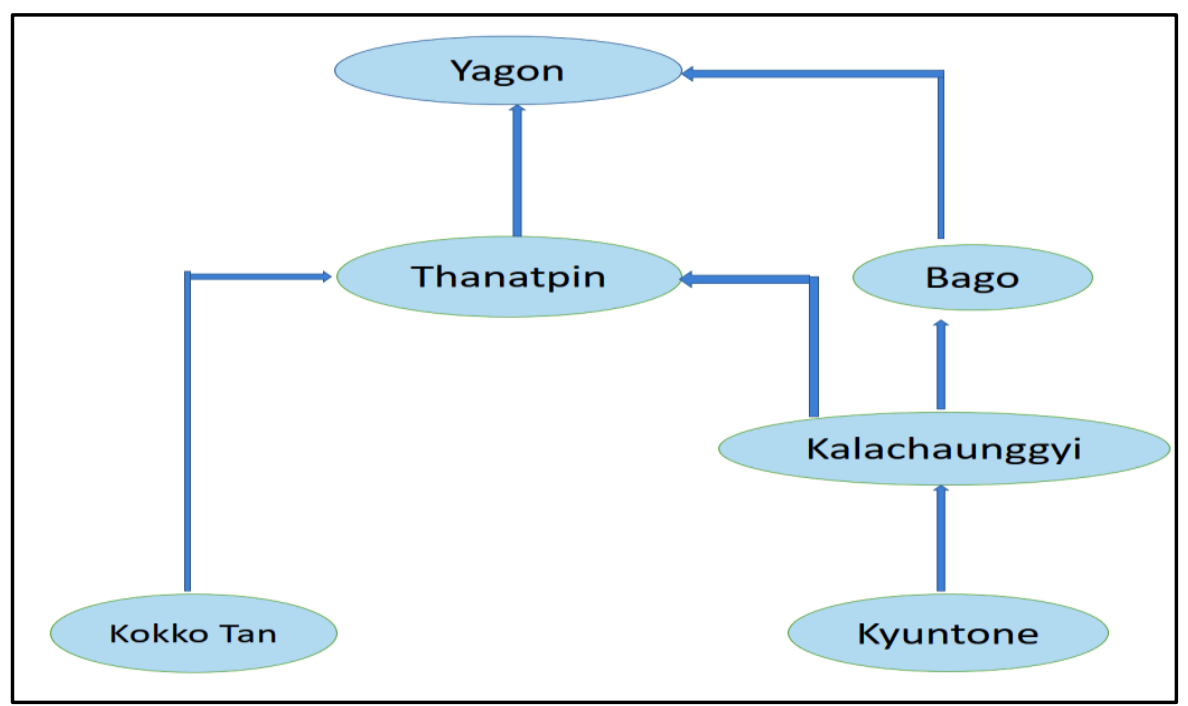

Figure 19. Value Chain of Sea bass.

Fishermen daily catch fish in GoMW to sell their local dealers in their village, or neighbouring villages. Among many species of wetland fishes, Sea bass (Ka-kadit) is the high price fish in Myanmar and $87 \%$ of fish eater are favor, to eat sea bass (ka-kadit) due to its yummy taste and thus sea bass becomes one of the important commercial fish species for increasing demand of fish eaters. Moreover, sea bass or barramundi or Lates calcarifer $[14,35]$ is a commercially valuable, carnivorous, marine teleost fish, the largest order of vertebrates, comprising $\sim 40 \%$ of all bony fishes (e.g., cichlids, sunfishes/bluegills, damselfishes, basses, and perches) and a wide geographic distribution [101, 150, 158]. Dealers 
usually give advances money and in this way the fishers are fixed with their dealer. Although the fishermen were sometime sell to the other dealers. The small-scale village dealers buy the sea bass from regular of about 20 fishers in Kokko Tan that operates on a large scale sending to their fishes to Bago Division. The next way is sent to Yangon Division, the main international trading place of Myanmar. In time of wild pond harvest, some fish owner directly sent to Bago Division or Yangon Division. There is no small scale fish collector in Kyuntone. So, the small-scale neighbouring villages of Kalachaungyi dealers were buys sea bass and others fishes from approximately 15 fisher regularly in kyuntone. The next way is Kyuntone to Thanatpin Township and Bago Division. The third way is Thanatpin and Bago sell to Yangon (Figure 16). Sea bass is the highest price in Yangon.

\section{Discussion}

During the study period, the largest number of fish in the 31-35 cm category were found in Kyuntone in January to March while very few were found in Kokko Tan. Fish > $35 \mathrm{~cm}$ were found in Kyuntone during January to March, while only a very few where found in Kokko. The largest size 39-47 cm that will not found at Kokko Tan. This may be suggest that size range of sea bass in Kyuntone was larger than in Kokko Tan (Table 1, Figure 9, 10, 11).

In Kokko Tan, mean value of standard length and body weight were highest in March $(32.70 \pm 1.58,660.7 \pm 112.23)$. The mean value of standard length was peak in January (31.39 \pm 7.16$)$ but mean value of body weight were peak in March $(963.24 \pm 280.86)$ in Kyuntone. According to this point, sea bass were nearly mature and migrate to spawning ground. The lowest mean value of standard length and body weight were found in June $(12.62 \pm 4.78,87.33 \pm 66.62),(9.07 \pm 0.85,43.97 \pm 16.66)$ in Kokko Tan and Kyuntone. This may be due to young specimens were returned from sea to freshwater to spend most of their lives (Table 2, Figure 12).

According to the invoice data revealed that monthly catch weight of sea bass is most abundance in October (829.92) kg in Kokko, (339.12) kg in Kyuntone. October was nearly end of the raining season, in all channels, creeks and lakes were shallow water. So, fishes are caught more readily in October when the water level is low. Moreover, Wild ponds were start harvest in this month. The lowest in March (22.4) kg in Kokko and (48.52) kg in Kyuntone. It may be due to migrate to the sea to breed (Table 3, Figure 13).

Based on price of relations to size group, small size $C<300 \mathrm{~g}(41 \%)$ was mostly abundance in Kokko and in Kyuntone small size C<300g (35\%) was second abundance. Size group C included very small specimens of under $165 \mathrm{~g}$. This size is prohibited by Department of fishery therefore this size should not be catched and follow the law of fisheries especially during the breeding season of April to July (Table 4, Figure 14).

According to the recorded data, prices of all size groups A>600g, B300-600g, C <300 were highest in March $(6825,5958.33,48750) \mathrm{MMK} / \mathrm{kg}$ in Kokko and $(7280,6120,5281.25)$ $\mathrm{MMK} / \mathrm{kg}$ in Kyuntone. Lowest price of A, B, C were observed in October (4296.72,3224.67, 2441.11) MMK/kg in Kokko and $(3075,2502.5,1755) \mathrm{MMK} / \mathrm{kg}$ in November, respectively. Price sizes of Kokko and Kyuntone were fluctuated for every month. This may be dependent on daily catch weights of two villages (Table 5, Fig 15).

Specimens were not landed in April and May. They migrate to spawn to the sea in these months [48-50,71,98,138]. Very small specimens were often observed with tides in April and May informed by local fisherman. In June, young specimens were very rarely seen in both study sites.

Lates calcarifer is Catadromous migrating to the mouth of the river and estuaries in order to breed $[95,96,109,131,152]$. There is one spawning season per year towards the end of the dry season and the beginning of raining season in the period from October to February [96]. In this study, the findings are not coincide with the finding of above authors. This may be due to the environmental difference of studied areas.

April and May is the onset of breeding season in sea bass and June is start growing months; onset of the raining season and coincide with the spawning period. For the sustainability of sea bass, should be aware of knowledge sharing to local people especially 
fisherman focus on breeding season to follow 'the fishery act' by Department of fishery and participate in conservation management.

\section{Conclusions}

Sea bass is the most popular commercial fish in South East Asia and the Gulf of Mottama Wetland (GoMW) is suitable habitat for sea bass. In this study, Kokko Tan village is nearer GoMW than Kyuntone village and both villages are prior to fishery and cultivation on farmland. Wetland fish species are valuable for both conservation ecosystem service and commercial status and they are main sources of food. Human Capital for fishery and cultivation is enough in Kokko Tan and Kyuntone village, nevertheless, social capital and manufacture capital are needed to improve for economic valuation of those two villages and GoMW. By the reason of low income of households, $12 \%$ of people in student ages are just working without schooling and thus, the educational status of those two villages are bad prospects for educated human capital. The villagers are familiar with fishery since their adolescences and thus, if they have knowledge for conservation of environment, especially wetland areas, human capital can improve natural capital, financial capital, social capital and also manufacture capital by systematical trading of natural resources of GoMW.

Author Contributions: Conceptualization, P.M.; methodology, P.M. and S.M.H.; software, P.M.; validation, K.S.W and N.N.M; resources, P.M. and K.S.W.; data curation, S.M.H, C.H and H.L.; writing - original draft preparation, P.M.; writing - review and editing, P.M and C.H.; supervision, C.H and K.S.W. All authors have read and agreed to the published version of the manuscript.

Funding: This research was funded by Department of Zoology, Bago University, Bago Division, Myanmar, (08018).

Acknowledgments: In this section, you can acknowledge any support given which is not covered by the author contribution or funding sections. This may include administrative and technical support, or donations in kind (e.g., materials used for experiments).

Conflicts of Interest: The authors declared that there is no potential conflicts of interest with this research, authorship and publication of this article. The authors took the responsibilities, concerning with our research.

\section{References}

1. Aarif, K.M.; Nefla, A.; Muzaffar, S.B.; Musammilu, K.K and Prasadan, A. 2017. Traditional fishing activities enhance the abundance of selected waterbird species in a wetland in India. Avian Res 8: 1-10, doi: https://doi.org/10.1186/s40657-017-0073-6

2. Abraha, B.; Admassu, H.; Mahmud, A.; Tsighe, N.; Shui, X.W and Fang, Y. 2018. Effect of processing methods on nutritional and physico-chemical composition of fish: a review. MOJ Food Process Technol 6(4): 376-382, doi: 10.15406/mojfpt.2018.06.00191

3. Alain Lambert, Economic Valuation of Wetlands: an Important Component of Wetland Management Strategies at the River basin Scale, May 2003, 1-10, Available online : http://webcache.googleusercontent.com/search?q=cache:p3FNj8UQjFcJ:www.unepscs.org/Economic_Valuation_Training_Materials/06\%2520Readings\%2520on\%2520Economic\%2520Valuation\%2520of\%2520Coastal\%2520Habitats/07-Economic-Valuation-Wetlands-Management.pdf $+\& c d=1 \& h l=e n \& c t=c l n k \& g l=m m \& c l i e n t=f i r e f o x-b-d,($ accessed on 18 February 2021).

4. A. Lawrence Kolz and J.B. Reynolds. Electrofishing, January 2012, Available online: https://www.researchgate.net/publication/280600972_Electrofishing, (accessed on 18 February 2021).

5. Alleyne, H. G and Macleay, W. 1877.The ichthyology of the Chevert expedition. Proceedings of the Linnean Society of NewSouth Wales 1: 261-281, 321-359, Pls. 3-9, 10-17, doi: https://doi.org/10.5962/bhl.part.12420

6. Al-Tobasei, R., Ali, A., Garcia, A.L.S., Lourenco. D., Leeds. Tim., and Salem. M. 2021.Genomic predictions for fillet yield and firmness in rainbow trout using reduced-density SNP panels. BMC Genomics 22, 92, doi: https://doi.org/10.1186/s12864-02107404-9, Available on: https://bmcgenomics.biomedcentral.com/articles/10.1186/s12864-021-07404-9

7. Angela H. Arithington, Nicholas K. Dulvy, William Gladstone, Ian J. Winfield. 2016. Fish conservation in freshwater and marine realm: status, threats and management, 28, September, 2016, 26(5): 838-857, doi: https://doi.org/10.1002/aqc.2712, Available online: https://onlinelibrary.wiley.com/doi/full/10.1002/aqc.2712

8. Asian Biodiversity outlook 2, 14, August, 2017, Available online: https://issuu.com/acb_abo2/docs/asean_biodiversity_outlook_2_b1e2a2a6646bd6 (accessed on 18 February 2021).

9. Barrett, R. D. H and Hebert, P. D. N. (2005). Identifying spiders through DNA barcodes. Can. J. Zool 83: 481-491, doi: 10.1139/z05024 
10. Basheer, V S and Vineesh, N and Bineesh, K K and Kumar, Rahul G and Mohitha, C and Venu, S and Kathirvelpandian, A and Gopalakrishnan, A and Jena, J K. 2017. Mitochondrial signatures for identification of grouper species from Indian waters. Mitochondrial DNA, 28 (4): 451-457, Available online: http://eprints.cmfri.org.in/view/creators/Basheer=3AV_S=3A=3A.html

11. Bhatia, U and Kungvankij, P. 1971. Distribution and abundance of seabass fry in coastal area of the province facing Indian Ocean. Annual report, Phuket Marine Fisheries Station. 14p

12. Bishnu B. Bhandari Reiko Nakamura Amado S. Tolentino and Jr. Shiina Suzuki. 2014. Catalyzing the Wise Use of Wetlands in Myanmar: Efforts and Ways Forward, Ramsar Center Japan, Available online: http://rcj.o.oo7.jp/english/Myanmar\%20Report.pdf, (accessed on 18 February 2021).

13. Bloch, M.E. (1787) Naturgeschichte der ausländischen Fische, vol. 3. Berlin, i-xii + 1-146, Pls. 181-216

14. Bloch, M.E. (1790) Naturgeschichte der ausländischen Fische. Morino, Berlin. Vol. 4, i-xii+1-128, Pls. 217-252. Bloch, M. E. (1797) Ichthyologie, ou Histoire naturelle, générale et particulière des poissons. Avec des figures enluminées dessinées d'apres nature, part 7. Published by the author, Berlin

15. Bloch, M.E. \& Schneider, J.G. (1801) M. E. Blochii, Systema Ichthyologiae iconibus cx illustratum. Post obitum auctoris opus inchoatum absolvit, correxit, interpolavit Jo. Gottlob Schneider, Saxo. Berolini, lx + 584 pp., 110 pl

16. Bouvier LD, Cottenie K, Doka SE. 2009. Aquatic connectivity and fish metacommunities in wetlands of the lower Great Lakes. Can J Aquat Sci 66: 993-948, doi: https://doi.org/10.1139/F09-050

17. Bruton, M. N and Jackson, P. B. N. 2010. FISH AND FISHERIES OF WETLANDS, Journal of the Limnological Society of Southern Africa, Oct 2010, 123-133, doi: 10.1080/03779688.1983.9632865

18. CCFFRR Program, Available online: http://www.phys.ocean.dal.ca/ccffr/images/CCFFR-SCL\%20abstracts.doc (accessed on 18 February 2021).

19. Charles A. Rewa. 2007. Fish and Wildlife Benefits Associated with Wetland Establishment Practices, The Wildlife Society Technical Review 07(1): 71-82, Available online: https://www.fsa.usda.gov/Internet/FSA_File/chap_5.pdf

20. Charlie, What does Sea bass Taste like? 2, March, 2021, Available online: https://preparedcooks.com/what-does-sea-bass-tastelike/

21. Chassaing, O., Hanni, C., and Berrebi, P. (2011). Distinguishing species of European sturgeons Acipenser spp. using microsatellite allele sequences. J. Fish Biol 78: 208-226. doi: 10.1111/j.1095-8649.2010. 02852.x

22. Chen, I.-C., Hill, J. K., Ohlemüller, R., Roy, D. B and Thomas, C. D. 2011. Rapid range shifts of species associated with high levels of climate warming. Science 333(6045): 1024-1026, doi: https://doi.org/10.1126/ science.1206432

23.Chen, W.-J., and Mayden, R. L. 2010. A phylogenomic perspective on the new era of ichthyology. BioScience 60: 421-432, doi: 10.1525/bio.2010.60.6.6

24. Chou, R., and Lee, H. B. 1997. Commercial marine fish farming in Singapore. Aquacult. Res 28: 767-776, doi: 10.1111/j.1365-2109. 1997.tb01001.x

25. Christoph Zöckler, Enhancing the conservation of wetlands in Myanmar: the government designates part of the Gulf of Mottama [EAAF117] in Mon State as Myanmar's fourth Ramsar site, January 2017, Available online: https://www.m-h-s.org/media/gom_ramsar_designation_article.pdf (https://www.eaaflyway.net/enhancing-the-conservation-of-wetlands-in-myanmarthe-government-designates-part-of-the-gulf-of-mottama-eaaf117-in-mon-state-as-myanmars-fourth-ramsar-site/, (accessed on 18 February 2021).

26. Christoph Zöckler. Nature-tourisms in Myanmar, Arccona Consulting, Retrieved from: https://www.ltandc.org/wp-content/uploads/2015/01/Myanmar-nature-tourism1.pdf.

27. Co- Chair of the working group, 2020. Scientific Publications, Available online: https://www.ccacoalition.org/en/content/cochairs-working-group, (accessed on 18 February 2021).

28. Collazo, Jaime A., James F. Gilliam, and Leopoldo Miranda-Castro. 2010. "Functional Response Models to Estimate Feeding Rates of Wading Birds." Waterbirds: The International Journal of Waterbird Biology 33(1): 33-40. Accessed March 8, 2021. Available online: http://www.jstor.org/stable/40660949

29. Constantinos C. Mylonas, Fernando De La Gándara, Aldo Corriero \& Antonio Belmonte Ríos, Atlantic Bluefin Tuna (Thunnus Thynnus) Farming and Fattening in the Mediterranean Sea, Available online: https://www.researchgate.net/publication/232733763_Atlantic_Bluefin_Tuna_Thunnus_Thynnus_Farming_and_Fattening_in_the_Mediterranean_Sea, (accessed on 18 February 2021).

30. Cuvier, G. 1816. Le Règne Animal distribu d'après son organisation pour servir de base l'histoire naturelle des animaux et d'introduction l'anatomie comparée. Les reptiles, les poissons, les mollusques et les annélides. Deterville, Paris. Vol. 2, i-xviii+1-532

31. Cuvier, G. \& Valenciennes, A. 1828. Histoire naturelle des poissons. Tome second. Livre Troisième. Des poissons de la famille des perches, ou des percoïdes. Levrault, Paris. i-xxi+2+1-490

32. Cynthia A, Paszkowski, William M. Tonn. 2000. Community concordance between the fish and aquatic birds of lakes in northern Alberta, Canada: the relative importance of environmental and biotic factors 43(3): 421-437, doi: https://doi.org/10.1046/j.1365-2427.2000.00512.x

33. Danone, World Wetlands Day 2007- Fish for Tomorrow, Retrieved From: https://www.ramsar.org/sites/default/files/documents/library/wwd2007_leaflet_e.pdf

34. da Silva, H.P., Petry, A.C and da Silva, C.J. 2010. Fish communities of the Pantanal wetland in Brazil: evaluating the effects of the upper Paraguay river flood pulse on baía Caiçara fish fauna. Aquat Ecol 44: 275-288, doi: https://doi.org/10.1007/s10452009-9289-9 
35. DeAngelis, D.L., J.C. Trexler and W.F. Loftus. 2005. Life history trade-offs and community d dynamics of small fishes in a seasonally pulsed wetland. Canadian Journal of Fisheries and Aquatic Sciences 62(4): 781-790, Available online: https://digitalcommons.fiu.edu/fce_lter_journal_articles/71/

36. Deepikaawasthi, the variety of Flora and Fauna in an area, 31, August, 2020, Available online: https://brainly.in/question/21885611, (accessed on 18 February 2021).

37 Digital Collection, Course booklet, Portal Arizon. 2011, Available online: https://digital.lib.usf.edu/SFS0046442/00001, (accessed on 18 February 2021).

38. Dr. Bishnu B. Bhandari, Ms. Reiko Nakamura, Mr.KimihikoMaekawa and Dr. Pyae Phyo Aung. 2017. Rapid Assessment of the Gulf of Mottama(East Coast), Ramsar Center Japan \& Biodiversity \& Nature Conservation Association 2017, 1-20, Available online: $\quad$ https://cdn.myanmarseo.com/file/client-cdn/banca/wp-content/uploads/2018/05/rapid-assessment-of-the-gulf-ofmottama.pdf

39. Dr. Panwad Wongthong and Dr. James True. 2015. Community-Led Coastal management in the Gulf of Mottama Project (CLCMGoMP), Updated situation analysis of the Gulf of Mottama, based on the rapid socio-ecological assessment, September, 2015, 1-40, Available online: https://themimu.info/sites/themimu.info/files/assessment_file_attachments/CLCMGoMP_IUCN_O3_Ecology_Assessment_Report_FinalDraft_Sep2015.pdf, (accessed on 18 February 2021).

40. Ecosystem and Human Well-Being: Wetlands and Water Synthesis. 2005. A Report of the Millennium Ecosystem Assessment Hardcover, Available online: https://www.amazon.com/Ecosystems-Human-Well-Being-Millennium-Assessment/dp/1569735972, (accessed on 18 February 2021).

41. EPA, May 2006, Economic Benefits of Wetlands, United States Environmental Protection Agency, Available online: https://www.epa.gov/sites/production/files/2021-01/documents/economic_benefits_of_wetlands.pdf, (accessed on 18 February 2021).

42. ERSS, Barramundi (Lates calcarifier), U.S. Fish and Wildlife Service, Ecological Risk Screening Summary, 13, Sep 2017, Retrieved from https://www.fws.gov/fisheries/ans/erss/uncertainrisk/Lates-calcarifer-ERSS-FINAL.pdf, (accessed on 18 February 2021).

43. Eschmeyer, W.N. (ed.), 2011, Catalog of Fishes, electronic version. Retrieved from: http://www.fao.org/fishery/culturedspecies/Lates_calarifer/en, (accessed on 18 February 2021).

44. Family Latidae - Lates perches, Available online: https://www.fishbase.se/summary/FamilySummary.php?ID=631, (accessed on 18 February 2021).

45. Fishbase .org. summary. Lates-calcarifer, Barramundi: Fisheries,aquaculture, game fish....Fish base, Available online: http://fishbase.sinica.edu.tw/summary/speciessummary.php?genusname=lates\&speciesname=cakcarifer, (accessed on 18 January 2021).

46. Fishbase References Starting with ' $\mathrm{M}^{\prime}$, Available online: http://wpbp.sinica.edu.tw/ListByLetter/FBReferencesM.htm, (accessed on 18 January 2021).

47. Fulton-Howard, B. 2008. "Lates calcarifer" (On-line), Animal Diversity Web. https://animaldiversity.org/accounts/Lates_calcarifer/, (accessed on 18 January 2021).

48. Grace Mathew. 2009. Taxonomy, identification, and biology of Seabass (Lates calcarifer), National Training on 'Cage Culture of Seabass' held at CMFRI, Kochi, 38-43, Available online: http://eprints.cmfri.org.in/6062/1/7._Gra.pdf

49. Garcia,L.M.B. (1989a). Dose-dependent spawning response of mature female seabss, Lates calcarifer (Bloch), to pelleted luteinizing hormone-releasing hormone analogue (LHHa). Aquaculture 77:85-96

50. Garcia, L.M.B. (1989b). Spawning response of mature female seabass, Lates calcarifer (Bloch, 1790) to a single injection of luteinizing hormone releasing hormone analogue and methyltestosterone. Journal of Applied Icthyology 5:155-184.

51 GRENADA, Economy, Citizenship by investment. Available online: https://www.cbi.gov.gd/why-grenada/economy/, (accessed on 18 January 2021).

52. Global New Light of Myanmar, Article, 10 May 2007, Myanmar, Available online: https://issuu.com/myanmarnewspaper/docs/10_may_17_gnlm, (accessed on 18 January 2021).

53. Guiguen, Y., C. Cauty, A. Fostier, J. Fuchs, and B. Jalabert. 1993. Reproductive cycle and sex inversion of the seabass, Lates calcarifer, reared in sea cages in French Polynesia: histological and morphometric description. Environmental Biology of Fishes 39(3): 231- 247

54. Gulf of Mottama Project (GoMP), Sustainable and wise use of wetland area for benefits of community livelihoods and conservation of coastal natural resources in the Gulf of Mottama, Myanmar, Helvetas Swiss Intercooperation: the international Union for Conservation of Nature (IUCN), Network Activities Group (NAG), Biodiversity and Nature Conservation Association (BANCA), Available online: https:/www.eda.admin.ch/dam/countries/countries-content/myanmar/en/helvetas-gulf-ofmottama-2018.pdf, (accessed on 18 January 2021).

55. Gulf of Mottama, Management Plan, May 2019, Available online: https://rsis.ramsar.org/RISapp/files/39465170/documents/MM2299_mgt191206.pdf, (accessed on 18 January 2021).

56. Hamilton, F.1822. An account of the fishes found in the river Ganges and its branches. Edinburgh \& London, i-vii+1-405, pls. 1-39, doi: https://doi.org/10.5962/bhl.title.6897

57. Hamre, J. 1994. Biodiversity and exploitation of the main fish stocks in the Norwegian - Barents S ea ecosystem. Biodivers Conserv 3: 473-492, doi: https://doi.org/10.1007/BF00115154

58. He-Bo Peng.; Guy Q. A.; Anderson., Qing Chang.; Chi-Yeung Choi.; Sayam U. Chowdhury.; Nigel A. Clark.; Xiaojing Gan.; Richard D. Hearn.; and et al. 2017. The intertidal wetlands of southern Jiangsu Province, China - globally important for Spoonbilled Sandpipers and other threatened waterbirds, but facing multiple serious threats, Bird Conservation International 27(3): 
305 - 322, doi: https://doi.org/10.1017/S0959270917000223, Available online: https://www.researchgate.net/publication/318594457_The_intertidal_wetlands_of_southern_Jiangsu_Province_China_-_globally_important_for_Spoonbilled_Sandpipers_and_other_threats

59. Hickling, R.; Roy, D. B.; Hill, J. K.; Fox, R and Thomas, C. D. 2006. The distributions of a wide range of taxonomic groups are expanding polewards. Global Change Biology 12(3): 450-455. doi: https://doi. org/10.1111/j.1365-2486.2006.01116.x.

60. Husson Bérengè.; Certain Gregoire and Filin Anatoly. 2020. Planque Benjamin Suitable habitats of fish species in the Barents Sea. BioRxiv IN PRESS. Publisher's official version: https://doi.org/10.1101/2020.01.20.912816, Open Access version: https://archimer.ifremer.fr/doc/00605/71682/

61. Hu, Q.; Wen, Y.; Yu, G.; yin, J.; Guan, H.; Lv, L.; Wang, P.; Xu, J.; Wang, Y.; Zhand, Z and et al. 2020. Research activity does not affect nest predation rates of the Silver-throated Tit, a passerine bird building domed nests. Avian Res 11, 28: 1-10, doi: https://doi.org/10.1186/s40657-020-00214-9, Available on: https://avianres.biomedcentral.com/articles/10.1186/s40657-02000214-9

62. Irmawati Irmawati1.; Moh. Tauhid Umar1.; Aidah Ambo Ala Husain.; Asmi Citra Malina.; Nadiarti Nurdin Kadir and Alimuddin Alimuddin, 2020. Distribution and characteristics of Asian seabass (Lates calcariferBloch, 1790) in South Sulawesi, The 3rd International Symposium Marine and Fisheries (ISMF) 2020, IOP Conf. Series: Earth and Environmental Science564 (2020) 012011: 1-8, doi: 10.1088/1755-1315/564/1/012011

63. Jan-Olaf Meynecke.; Geoffrey C. Poole.; Jonathan Werry and Shing Yip Lee. 2008. Use of PIT tag and underwater video recording in assessing estuarine fish movement in a high intertidal mangrove and salt marsh creek, Estuarine, Coastal and Shelf Science 79(1): 168-178, ISSN 0272-7714, doi: https://doi.org/10.1016/j.ecss.2008.03.019 Available on: https://www.sciencedirect.com/science/article/pii/S0272771408001406

64. Jeffery A. Zinn and Claudia Copeland, CRS Report for Congress, Wetlands: An overview of Issues, Congressional Research Service, 26, July, 2007, Available online: https://www.countyofsb.org/ceo/asset.c/508, (accessed on 18 January 2021).

65. Jerome J. Lorenz.; Brynne Langan-Mulrooney.; Peter E. Frezza.; Rebecca G. Harvey and Frank J. Mazzotti. 2008. Roseate spoonbill reproduction as an indicator for restoration of the Everglades and the Everglades estuaries, 9(6): S96-S107, doi: 10.1016/j.ecolind.2008.10.008, Available on: https://www.researchgate.net/publication/222430492_Roseate_spoonbill_reproduction_as_an_indicator_for_restoration_of_the_Everglades_and_the_Everglades_estuaries

66. Jérôme Pelenc and Jérôme Ballet. 2015. Strong sustainability, critical natural capital and the capability approach (2015) Ecological Economics 112: 36-44, doi: https://doi.org/10.1016/j.ecolecon.2015.02.006, Available on: https://www.researchgate.net/publication/284078771_Strong_sustainability_and_critical_natural_capital

67. Kaller M.D.; Kelso W.E and Trexler J.C. 2013. Wetland Fish Monitoring and Assessment. In: Anderson J., Davis C. (eds) Wetland Techniques. Springer, Dordrecht 197-263, doi: https://doi.org/10.1007/978-94-007-6931-1_6

68. Kelvin S.H. Peh.; Jennifer C. Merriman.; Thiri Dae We Aung.; Saw Mon Theint.; Natsuki Murata and Keiko Suzue. 2015. Economic Valuation of Moeyungyi Wetland, Rapid ecosystem services assessment of Moeyungyi Wetland, Myanmar, BirdLife International, Tokyo, Japan, March, 2015, Available online: https://cdn.myanmarseo.com/file/client-cdn/banca/wp-content/uploads/2020/09/Economic-Valuation-of-Moeyungyi-Wetland-Myanmar_compressed.pdf, (accessed on 18 December 2020).

69. Kewal Prasad Bhandari (2018), Development Partner Profile 20180406054531 Available online: https://www.scribd.com/document/396881379/Development-Partner-Profile-20180406054531, (accessed on 18 February 2021).

70. Kungvankij (1981). Seed production of seabass. Satun Fisheries Station. Contribution No. 1. Satun,Thailand. 15p

71. Kungvankij,P. 1987. Induction of spawning of seabass (Lates calcarifer) by hormone injection and environmental manipulation. In: J.W. Copland and D.L. Grey (eds.). Management of Wild and Cultured Seabass / Barramundi (Lates calcarifer). Australian Centre for International Agricultural Research, Canberra, 120-122.

72. Lacepède, B.G.E. 1802. Histoire naturelle des poissons. Paris, Plassan. Vol. 4, i-xliv+1-728, Pl. 1-16

73. Lakerveld, J.; van der Ploeg, H.P.; Kroeze, W and et al. 2014. Towards the integration and development of a cross-European research network and infrastructure: the DEterminants of DIet and Physical ACtivity (DEDIPAC) Knowledge Hub. Int J Behav Nutr Phys Act 11: 143: 1-10, doi: https://doi.org/10.1186/s12966-014-0143-7, Available online: https://ijbnpa.biomedcentral.com/articles/10.1186/s12966-014-0143-7

74. Lates, Entymology, Scientific classification, Available online: https://www.h4ckerz.com/Lates, (accessed on 18 February 2021).

75. Lin, Y.-A.; Chu, P.-Y.; Ma,W.-L.; Cheng, W.-C.; Chan, S.-T.; Yang,J.-C and Wu, Y.-C. 2021. Enzyme-DigestedPeptides Derived fromLates calcariferEnhance Wound Healing afterSurgical Incision in a Murine Model.Mar. Drugs2021, 19(3): 154, 1-13 doi: https://doi.org/10.3390/md19030154, Available online: https://www.mdpi.com/1660-3397/19/3/154/pdf

76. Lenoir, J.; Bertrand, R.; Comte, L.; Bourgeaud, L.; Hattab, T.; Murienne, J and Grenouillet, G. 2020. Species better track climate warming in the oceans than on land. Nature Ecology \& Evolution 4: 1044-1059, doi: https://doi. org/10.1038/s41559-020-1198-2

77. Lorenz, J.J and Serafy, J.E. 2006. Subtroprical wetland fish assemblages and changing salinity regimes: Implications for everglades restoration. Hydrobiologia 569: 401-422. doi: https://doi.org/10.1007/s10750-006-0145-9

78. L Venkatachalam. 2004. Contingent valuation method: a review: Environmental Impact Assessment Review [Environ. Impact Assess. Rev.] 24(1): 89-124, doi: 10.1016/S0195-9255(03)00138-0, Available online: https://www.researchgate.net/publication/222433375_The_contingent_valuation_method_a_review_Environ_Impact_Assess_Rev

79. Madhu Rao.; Alan Rabinowitz and Saw Tun Khaing. 2002. Status Review of the Protected-Area System in Myanmar, with Recommendations for Conservation Planning, Conservation Biology 16(2): 360-368, doi: 10.1046/j.1523-1739.2002. 00219.x, Available online: https://www.researchgate.net/publication/229556820_Status_Review_of_the_Protected-Area_System_in_Myanmar_with_Recommendations_for_Conservation_Planning 
80. Mauricio A Urbina.; Malcolm E Forster and Chris N Glover. 2011. Leap of faith: voluntary emersion behavior and physiological adaptations to aerial exposure in a non-aestivating freshwater fish in response to aquatic hypoxia, 3, May, 2011; 103(2): 240-7, doi: 10.1016/j.physbeh.2011.02.009. Available online: https://www.researchgate.net/publication/49831520_Leap_of_faith_Voluntary_emersion_behaviour_and_physiological_adaptations_to_aerial_exposure_in_a_non-aestivating_freshwater_fish_in_response_to_aquatic_hypoxia

81. MC Cormier-Salem and J Panfili. 2016. Mangrove reforestation: greening or grabbing coastal zones and deltas? Case studies in Senegal, African Journal of Aquatic Science, 41(1): 89-98, doi: 10.2989/16085914.2016.1146122, Available online: https://www.researchgate.net/publication/299416773_Mangrove_reforestation_greening_or_grabbing_coastal_zones_and_deltas_Case_studies_in_Senegal

82. Myat Moe Aung, 3, February 2020, EPA, Gulf of Mottama Wetland more than triples in size as newest Ramsar. Available online: https://www.mmtimes.com > news, https://www.mmtimes.com/news/gulf-mottama-wetland-more-triples-size-newest-ramsar-site.html, (accessed on 18 February 2021).

83. Myat Moe Aung, Our Wetlands are worth saving, Available online: https://www.mmtimes.com/news/our-wetlands-are-worthsaving.html, (accessed on 18 February 2021).

84. Macleay, W.1878. The fishes of Port Darwin. Proceedings of the Linnean Society of New South Wales, 2, 344-367, Pls. 7-9

85. Matishov, G.; Moiseev, D.; Lyubina, O.; Zhichkin, A.; Dzhenyak, S.; Karamushko, O and Frolova, E. 2012. Climate and cyclic hydrobiological changes of the Barents Sea from the twentieth to twenty-first centuries. Polar Biol 35: 1773-1790. doi: https://doi.org/10.1007/s00300-012-1237-9, Available online: https://link.springer.com/article/10.1007/s00300-012-1237-9

86. MacKay KT. 2017. Introduction and review of research on the Gulf of Mottama: Environment and Fishery. Community-Led Coastal Management in the Gulf of Mottama Project, Available online: https://nagmyanmar.org/wp-content/uploads/2020/09/Paper-on-Co-Management-in-GOM_full-version.pdf, (accessed on 18 February 2021).

87. MacKay KT and Soe Min Oo. 2017. Illegal fishing with small mesh stake nets (Than Za Gar Pike) catching small fish: A case study. Community-Led Coastal Management in the Gulf of Mottama Project. Available online: http://webcache.googleusercontent.com/search?q=cache:vI6Jh40Acj8J:themimu.info/sites/themimu.info/files/assessment_file_attach-

ments/GoMP_Report0617_Illegal_Fishing_with_Small_Mesh.pdf+\&cd=1\&hl=en\&ct=clnk\&gl=mm\&client=firefox-b-d, $\quad(a c-$ cessed on 18 February 2021).

88. MatAmin, A. R.; Ahmad, F.; Mamat, M.; Abdullah, K and Harun, S. 2015. Remote sensing of suspended sediment over Gulf of Martaban. Ekológia (Bratislava) 34(1): 54-64.

89. Millennium Ecosystem Assessment (Ed). 2005. Ecosystems and human well-being: wetlands and water synthesis: a report of the Millennium Ecosystem Assessment. Washington, DC: World Resources Institute, Corup ID: 131450815, doi: 10.1515/eko2015-0006, (accessed on 18 February 2021).

90. McNeil DG and Closs GP. 2007. Behavioral responses of a south-east Australian floodplain fish community to gradual hypoxia. Freshw Biol 52: 412-420. doi: https://doi.org/10.1111/j.1365-2427.2006.01705.x

91. MDFRC (2013) Long-term Intervention Monitoring - Generic Cause and Effect Diagrams Final Report prepared for the Commonwealth Environmental Water Office by The Murray-Darling Freshwater Research Centre, MDFRC Publication 01.5/2013, May, 163pp. Available online: https://www.environment.gov.au/system/files/resources/5c555077-ecca-4e3d-8f1587f9d17bd75c/files/ltim-project-cause-and-effect-diagrams.docx

92. Melissa Nursey-Bray, Research Profile, Available online: https://researchers.adelaide.edu.au/profile/melissa.nursey-bray, (accessed on 18 February 2021).

93. Michael Sinclair.; M.K. Vishnu Sagar.; Camilla Knudsen.; Joseph Sabu and Andrea Ghermandi. 2021. Economic appraisal of ecosystem services and restoration scenarios in a tropical coastal Ramsar wetland in India, February, 2021, 47: 1-12, doi: https://doi.org/10.1016/j.ecoser.2020.101236, Available online: https://www.sciencedirect.com/science/article/pii/S2212041620301789

94. Min Moe, Myanmar- Scoping paper, Myanmar Coastal Zone Management 21113 96dpi, Available online: https://www.scribd.com/document/252202262/Myanmar-Scoping-Paper-Myanmar-Coastal-Zone-Management-211113-96dpi, (accessed on 18 February 2021).

95. Moore, R and Reynold, 1979. Natural sex inversion in the giant perch (Lates calcarifer). Australian Journal of Marine and Freshwater Research 30: 803-813.

96. Moore, R. 1982. Spawning and early life history of burramundi, Lates calcarifer (Bloch), in Papua New Guinea. Australian Journal of Marine and Freshwater Research 33(4): 647-661. Available online: http://www.publish.csiro.au/paper/MF9820647.htm, (accessed on 18 February 2021).

97. Morgan, D.; A. Rowland.; H. Gill and R. Duope. 2004. The implications of introducing a large piscivore (Lates calcarifer) into a regulated northern Australian river (Lake Kununurra, Western Australia), (9)3-4: 181-193, doi: https://doi.org/10.1111/j.14401770.2004.00247.x

98. Myanmmar, Ramsar, Retrieved from: https://www.ramsar.org/wetland/myanmar, (accessed on 18 February 2021).

99. Myat Moe Aung, Gulf of Mottama Wetland more than triples in size as newest Ramsar Site, 03, Feb, 2020 Retrieved From: https://www.mmtimes.com/news/gulf-mottama-wetland-more-triples-size-newest-ramsar-site.html

100. 20 Examples of Qualitative and Quantitative Variables, Available online: https://www.lifepersona.com/20-examples-of-qualitative-and-quantitative-variables

101. Nelson, J.S., Fish Diversity and Fish Assemblage Structure in Seagrass Meadows at Sikao Bay, Trang Province, Thailand, (2006), Fishes of the World. 4th Edition, John Wiley \& Sons, Hoboken, 601 p, Available online: 
https://www.scirp.org/(S(vtj3fa45qm1ean45vvffcz55))/reference/ReferencesPapers.aspx?ReferenceID=1633759, (http://as.wileyt.com/WileyCDA/WileyTitle/productCd-0471250317.html), (accessed on 18 February 2021).

102. Nguyen Thanh Nga, Yoshiro Higano and Helmut Yabar, Analyse. 2012. Wetland Economic Value : Case Study in Xuan Thuy National Park, Viet Nam, April 2012, 1-6, Available online: https://www.researchgate.net/publication/270392831_Analysis_of_Wetland_Economic_Value_Case_Study_in_Xuan_Thuy_National_Park_Viet_Nam

103. Our wetlands are worth saving, The Myanmar Times, 3-Oct-2019, Available online: https://www.mmtimes.com/news/our-wetlands-are-worth-saving.html, (accessed on 18 February 2021).

104. Paolo Parenti. 2020. An annotated checklist of fishes of the family Sciaenidae, IAD 2020, 2(1): 1-92, URL: https://jad.lu.ac.ir/article-1-49-en.html

105. Parmesan, C and Yohe, G. 2003. A globally coherent fingerprint of climate change impacts across natural systems. Nature 421(6918), 37-42. doi: https://doi.org/10.1038/nature01286

106. Peh, K.SH.; Balmford, A.; Birch, J.C.; Brown. C.; Butchart, S.H.M.; Daley, J.; Dawson, J.; Gray, G.; Hughes, F.M.R and et al. 2015. Potential impact of invasive alien species on ecosystem services provided by a tropical forested ecosystem: a case study from Montserrat. Biol Invasions 17: 461-475. doi: https://doi.org/10.1007/s10530-014-0743-9, Available online: https:/arro.anglia.ac.uk/346857/1/Peh\%20et\%20al\%202014\%20Biol\%20InvasionsPost-print\%202.pdf

107. Pethiyagoda, R. and A.C. Gill, 2012. Descriptions of two new species of sea bass (Teleostei: Latidae: Lates) from Myanmar and Sri Lanka. Zootaxa 3314:1-16. (Ref. 90099), Available online: https://www.fishbase.se/summary/66563

108. Pethiyagoda, R. and A.C. Gill, 2012. Lates uwisara, Available online: https://www.fishbase.de/summary/Lates-uwisara.html, (accessed on 18 February 2021).

109. Pender, P and R. Griffin. 1996. Habitat History of Barramundi Lates calcarifer in a North Austrian River System Based on Barium and Strontium Levels in Scales. Transactions of the American Fisheries Society 125: 679-689. Available online: http://afs.allenpress.com/perlserv/?request=getabstract\&doi=10.1577\%2F15488659(1996)125\%3C0679:HHOBI\%3E2.3.C0\%3B2\&ct=1

110. Planque, B., Lazure, P and Jegou, A.-M. 2006. Typology of hydrological structures modelled and observed over the Bay of Biscay shelf. Scientia Marina, 70(S1): 43-50. doi: https://doi.org/10.3989/ scimar.2006.70s143

111. Porter, M.; Stefansson, S.; Nyhammer, G.; Karlsen, Ø.; Norberg, B and Bromage N.R. 2000. Environmental influences on melatonin secretion in Atlantic cod (Gadus morhua L.) and their relevance to commercial culture. Fish Physiology and Biochemistry 23: 191-200. doi: https://doi.org/10.1023/A:1007816426509, Available online: https://www.researchgate.net/publication/226428815_Environmental_influences_on_melatonin_secretion_in_Atlantic_cod_Gadus_morhua_L_and_their_relevance_to_commercial_culture

112. Pusey, B., Kennard, M and Arthington, A. 2004. Freshwater fishes of north-eastern Australia. CSIRO Publishing, Collinwood, 684 pp, doi: https://doi.org/10.1002/rra.895

113. Rabanal, H.R. and Soesanto, V. 1982. Report of the Training course on seabass spawning and larval rearing - Songkhla, Thailand - 1 to 20, June 1982. FAO Corporate Document Repository, SCS/GEN/82/39, 120 pp. Available online: http:// www.fao.org/docrep/field/003/Q8694E/Q8694E00.htm, (accessed on 18 February 2021).

114. Rachael Hickling.; Jane K. Hill.; Richard Fox and Chris D. Thomas. 2006. The distribution of a wide range of taxonomic groups are expanding polewards 12(3): 450-455, doi: https://doi.org/10.1111/j.1365-2486.2006.01116.x Available online: https://onlinelibrary.wiley.com/doi/abs/10.1111/j.1365-2486.2006.01116.x

115 Ratamess, Nicholas A.; Rosenberg, Joseph G.; Klei, Samantha; Dougherty, Brian M.; Kang, Jie; Smith, Charles R.; Ross, Ryan E and Faigenbaum, Avery D. 2015. Comparison of the Acute Metabolic Responses to Traditional Resistance, Body-Weight, and Battling Rope Exercises, Journal of Strength and Conditioning Research: January 2015, 29 (1), 47-57 doi: 10.1519/JSC.0000000000000584, Available online: https://journals.lww.com/nsca-jscr/Fulltext/2015/01000/Comparison_of_the_Acute_Metabolic_Responses_to.6.aspx

116. Rahman, H.M.T.; Hickey, G.M and Sarker, S.K. 2015. Examining the Role of Social Capital in Community Collective Action for Sustainable Wetland Fisheries in Bangladesh. Wetlands 35, 487-499, doi: https://doi.org/10.1007/s13157-015-0635-5

117. Ramaswamy, V.; Rao, P. S.; Rao, K. H.; Thwin Swe.; Rao, N. S and Raiker, V. 2004. Tidal influence on suspended sediment distribution and dispersal in the northern Andaman Sea and Gulf of Martaban. Marine Geology 208, 33-42, Source: OAI, doi: 10.1016/j.margeo.2004.04.019

118. Ramsar Sites Information Service, Available online: https://rsis.ramsar.org/ris-search/myanmar?pagetab=1, (accessed on 18 February 2021).

119. Ramsar,Myanmar, Available online: https://www.ramsar.org/wetland/myanmar, (accessed on 18 February 2021).

120. RIS. 2020, Ramsar Information Sheet, RSIS V. 1.6., 1. Feb. 2020, RIS for Site no. 2299, Gulf of Mottama, Myanmar, Available online: https://rsis.ramsar.org/ris/2299, (accessed on 18 February 2021).

121. Recreational Sea Bass Fishing volume 605: debated on Thursday 11 February 2016, Available online: https://hansard.parliament.uk/Commons/2016-02-11/debates/16021158000001/RecreationalSeaBassFishing, (accessed on 18 February 2021).

122. Recreational Sea Bass Fishing, 11, Equitable life- In the house of commons, February, 2016, Available online: https://www.theyworkforyou.com/debates/?id=2016-02-11c.1818.2, (accessed on 18 February 2021).

123. Rehage Jennifer $S$ and Loftus W.F. 2007.Seasonal fish community variation in headwater mangrove creeks in the southeastern Everglades: an examination of their role as dry-down refuges. USGS Publications Warehouse, Bull Mar Sci 80: 625-645, Available online: https://pubs.er.usgs.gov/publication/70029769, (https://about.illinoisstate.edu/lccomte/teaching/), (accessed on 18 February 2021). 
124. Richard T. Woodward and Yong-Suhk Wui. 2001. The economic value of wetland services: a meta-analysis, Ecological Economics 37(2): 257-270, ISSN 0921-8009, doi: https://doi.org/10.1016/S0921-8009(00)00276-7 , Available online: https://www.sciencedirect.com/science/article/pii/S0921800900002767

125. Rimmer, M.A and Russell, D.J. (1998) Survival of stocked barramundi, Lates calcarifer Bloch), in a coastal river system in far northern Queensland, Australia. Bulletin of Marine Science, 62: 325-336

126. Robert McInnes and Tint Tun. 2020. Mid- Term Review: Gulf of Mottama Project, Report to The Swiss Confederation, April, 2020, the Federal Department of Foreign Affairs, Embassy of Switzerland in Myanmar, PR113/R1.0/F: 1-42, Available online: https://www.iucn.org/sites/dev/files/gulf_of_mottama_phase_2_mid_term_review_2020.pdf, (accessed on 18 February 2021).

127. Robinson, R. A. J.; Bird, M. I.; Oo, Nay Win.; Hoey, T. B.; Aye, Maung Maung.; Higgitt, D. L.; X. X. Lu.; Swe, Aung.; Tun, Tin and Win, Swe Lhaing. 2007. The Irrawady River Sediment Flux to the Indian Ocean: The Original Nineteenth-Centuary Data Revisited, November 2007, The Journal of Geology 115(6): 629-640, doi: 10.1086/521607, Available online: https://ui.adsabs.harvard.edu/abs/2007JG.115.629R/abstract

128. Roegner GC.; Dawley EW.; Russell M.; Whiting A and Teel DJ. 2010. Juvenile salmonid use of reconnected tidal freshwater wetlands in Grays River, Lower Columbia River Basin. Trans Am Fish Soc 139: 1211-1232. doi: https://doi.org/10.1577/T09-082.1

129. Rohan Pethiyagoda and Anthony C. Gill. 2012. Description of two new species of sea bass (Teleostei: Latidae: Lates) from Myanmar and Sri Lanka, 16, May, 2012, ISSN 1175-5326, 1-16, doi: https://doi.org/10.11646/zootaxa.3314.1.1

130. Rue Mauverney, Fish for tomorrow? 2 February, World Wetlands Day, Daily Report of Ramsar Convention and its works, Available online: https://www.ramsar.org/sites/default/files/documents/library/wwd2007_leaflet_e.pdf, (accessed on 18 February 2021).

131. Russell, D., and R. Garrett. 1985. Early life history of barramundi, Lates calcarifer (Bloch), in north-eastern Queensland. Australian Journal of Marine and Freshwater Research 36(2) :191-20.

132. Sheaves $M$ and Johnston R. 2008. Influence of marine and freshwater connectivity on the dynamics of subtropical estuarine wetland fish metapopulations. Mar Ecol Prog Ser 357: 225-243, doi: https://doi.org/10.3354/meps07292

133. Snelson, F.; Williams-Hooper, S and Schmid, T. 1988. Reproduction and Ecology of the Atlantic Stingray, Dasyatis sabina, in Florida Coastal Lagoons. Copeia 3: 729-739, doi:10.2307/1445395, Available online: https://www.jstor.org/stable/1445395

134. Suprenand PM.; Drexler M.; Jones DL and Ainsworth CH. 2015. Strategic assessment of fisheries independent monitoring programs in the gulf of Mexico. Plos one 10(3): e0120929. doi: 10.1371/journal.pone.0120929, Available online: https://europepmc.org/articles/PMC4383601

135. Stuart Butchart, Ellen Dieme-AmTing, Habiba Gitay, Steve Raaymakers and Douglas Taylor. 2005. Millennium Ecosystem Assessment (Ed). Ecosystems and human well-being: wetlands and water synthesis: a report of the Millennium Ecosystem Assessment. Washington, DC: World Resources Institute, Available online: https://www.millenniumassessment.org/documents/document.358.aspx.pdf, (accessed on 18 February 2021).

136 Thailand Fish Photos and Information Barramundi, Asian Sea Bass, Available online: http://www.sea-ex.com/thailand/angling/barramundi.htm, (accessed on 18 February 2021).

137. Than Htike Aung. 2019. Gulf of Mottama Management Plan, (Report), 02-Jul-2019, HELVETAS-007, Development focused: Coordination Environment Governance Protection, Natural Resource Management, 1-42, Available online: https://themimu.info/sites/themimu.info/files/assessment_file_attachments/190606_CNRMP_EnVersion_Final.pdf, (accessed on 18 February 2021).

138. Thayer KA.; Taylor KW.; Garantziotis S.; Schurman SH.; Kissling GE.; Hunt D.; Herbert B.; Church R.; Jankowich R.; Churchwell MI and et al. 2016. Bisphenol A, bisphenol S, and 4-hydroxyphenyl 4-isoprooxyphenylsulfone (BPSIP) in urine and blood of cashiers. Environ Health Perspect 124: 437-444, doi: https://doi.org/10.1289/ehp.1409427, Available online: https://ehp.niehs.nih.gov/doi/10.1289/ehp.1409427

139. The Fish Sites, World Wetlands Day-Fish For Tomorrow? 5, May, 2007, Available online: https://thefishsite.com/articles/worldwetlands-day-fish-for-tomorrow, (accessed on 18 February 2021).

140. The Myanmar Time. 2020. Heartbeat of The Nation, Myanmar, September 23, Available online: https://pt.scribd.com/doc/255145272/201438767, (accessed on 18 February 2021).

141. The Myanmar Time. 2014. Heartbeat of The Nation, Myanmar, February 10-16, Available online: https://pt.scribd.com/doc/205995668/201435716. (accessed on 18 February 2021).

142. The Green Book (2020), Gov. UK, Available online: https://www.gov.uk/government/publications/the-green-book-appraisaland-evaluation-in-central-governent/the-green-book-2020, (accessed on 18 February 2021).

143. Thiha, Myanmar Times, Workshop on potential for sea bass success, 9, February, 2016, Available online: https://consult-myanmar.com/2016/02/09/workshop-on-potential-for-sea-bass-success/, (accessed on 18 February 2021).

144. Thomas, C. D. 2010. Climate, climate change and range boundaries. Diversity and Distributions 16(3): 488-495. doi: https://doi. org/10.1111/j.1472-4642.2010.00642.x

145. Toledo, J.D., C.L. Marte and A.R. Castillo.1991. Spontaneous maturation and Spawning of Seabass Lates Calcarifer in floating net cages. Journal of Applied Ichthoyl 7:217-222

146. Tin Tin Aye, (2004). Corralation between age, growth rate and sex reversal in sea bass Lates calcarifer (Bloch,1790) based on otholith, scale microstructure and length parameters, PhD. disseration, University of Yangon, Yangon, Myanmar.

147. Trebitz, A. S.; J. C. Brazner.; M. S. Pearson.; G. S. Peterson.; D. K. Tanner and D. L. Taylor. 2009. Patterns in Habitat and Fish Assemblages within Great Lakes Coastal Wetlands and Implications for Sampling Design. CANADIAN JOURNAL OF FISHERIES AND AQUATIC SCIENCES. NRC Research Press, Ottawa, Canada 66(8):1343-1354, 11- Aug-2009, doi: https://doi.org/10.1139/F09-090 
148. UN Fish and Agricultural Organization, 1999. FAO species identification guide for fishery purposes: the living marine resources of the western central Pacific; Volume 4 Bony fishes part 2 (Mugilidae to Carangidae). Publications Division, Food and Agriculture Organization of the United Nations, Rome.

149. UN Fish and Agricultural Organization, 2008. Barramundi (=Giant seaperch) - Lates calcarifer. FAO Fisheries and Aquaculture - Species fact sheets. Available online: http://www.fao.org/fishery/species/3068. (accessed on 18 February 2021).

150. Vij, Shubha.; Kathireshan, P.; Gopikrishna, G.; Lau, D.; Saju, J M.; Shamsudheen, K V.; Vinayakumar, K.; Basheer, V S.; Gopalakrishnan, A and et al. 2014. Barcoding of Asian seabass across its geographic range provides evidence for its bifurcation into two distinct species. Frontiers in Marine Science Editorial Office 1 (30): 1-17, doi: 10.3389/fmars.2014.00030. Available online: https://www.researchgate.net/publication/264458676_Barcoding_of_Asian_seabass_across_its_geographic_range_provides_evidence_for_its_bifurcation_into_two_distinct_species

151. Ward, R.D.; Holmes, B.H and Yearsley, G.K. 2008. DNA barcoding reveals a likely second species of Asian sea bass (barramundi) (Lates calcarifer). Journal of Fish Biology 72, 458-463, doi: https://doi.org/10.1111/j.1095-8649.2007.01703.x

152. Webster, C and C. Lim. 2002. Nutrient Requirements and Feeding of Finfish for Aquaculture.Wallingford, Oxon; New York, NY: CABI Publishing. Available online: http://books.google.com/books?1r=\&id=9Vohcd01SJQC, (accessed on 18 February 2021)

153. Wetland Conservation in Myanmar, CMS/CAF/Inf.14. Available online: https://www.cms.int/sites/default/files/document/inf_04_14_Myanmar_0.pdf, (accessed on 18 February 2021).

154. Wilmington, N.C., Up- To Date, 1902, Available online: https://docsouth.unc.edu/nc/uptodate/uptodate.html, (accessed on 18 February 2021).

155. World Wetland Day - “Fish for tomorrow?" Available online: http://pubs.iclarm.net/resource_centre/WorldWetlandsDay_2.pdf, (accessed on 18 February 2021).

156. Workshop Feb 3, 2016 on potential for sea bass success I. The Myanmar Times. Available online: https: www.mmtimes.com> business, (accessed on 18 February 2021).

157. Yingthavorn, P. (1951) Notes on Pla-Kapong (Lates calcarifer Bloch) culturing in Thailand. FAO Fisheries Biology Technical Paper 20: 1-6.

158. Yu Yu Htwe, Thida Ei and Kalayar Win Maung, ARTIFICIAL PROPAGATION OF SEABASS, LATES CALCARIFER (BLOCH, 1790) IN MYEIK ARCHIPELAGO, J. Myanmar Acad. Arts. Sci 13(3): 341-353. Available online: http://maas.edu.mm/Research/download_details.php?id=804

159. Biden Harris, The Biden Plan To Build A Modern, Sustainable Infrastructure And An Equitable Clean Energy Future, Available online: https://joebiden.com/clean-energy/, (accessed on 18 February 2021).

160. Jean-François Noël and Martin O'Connor. 1998. Strong Sustainability and Critical Natural Capital, (C) Chapter 4 in: S. Faucheux \& M. O'Connor (eds., 1998) Valuation for Sustainable Development, Edward Elgar, Cheltenham UK, 75-97. Available online: https://www.researchgate.net/publication/284078771_Strong_sustainability_and_critical_natural_capital, (accessed on 18 February 2021).

161. 161. Fish of Mississippi, Department of Wildlife and Fisheries, Mississippi State University,

162. MississippiState, Mississippi, 39762, USA, Available online: https://www.cfr.msstate.edu/wildlife/fisheries/?a=detail\&id=4\&info $=$, (accessed on 18 January 2021). 